\title{
Población y desarrollo urbano de la ciudad de Denia
}

\author{
Ramona Ciudad Cludad *
}

\section{INTRODUCCIÓN}

El plano actual de Denia es el resultado de su ubicación histórica, así como de la creciente expansión que la ciudad ha ido sufriendo con la aparición de nuevas áreas, provocadas por el crecimiento de la

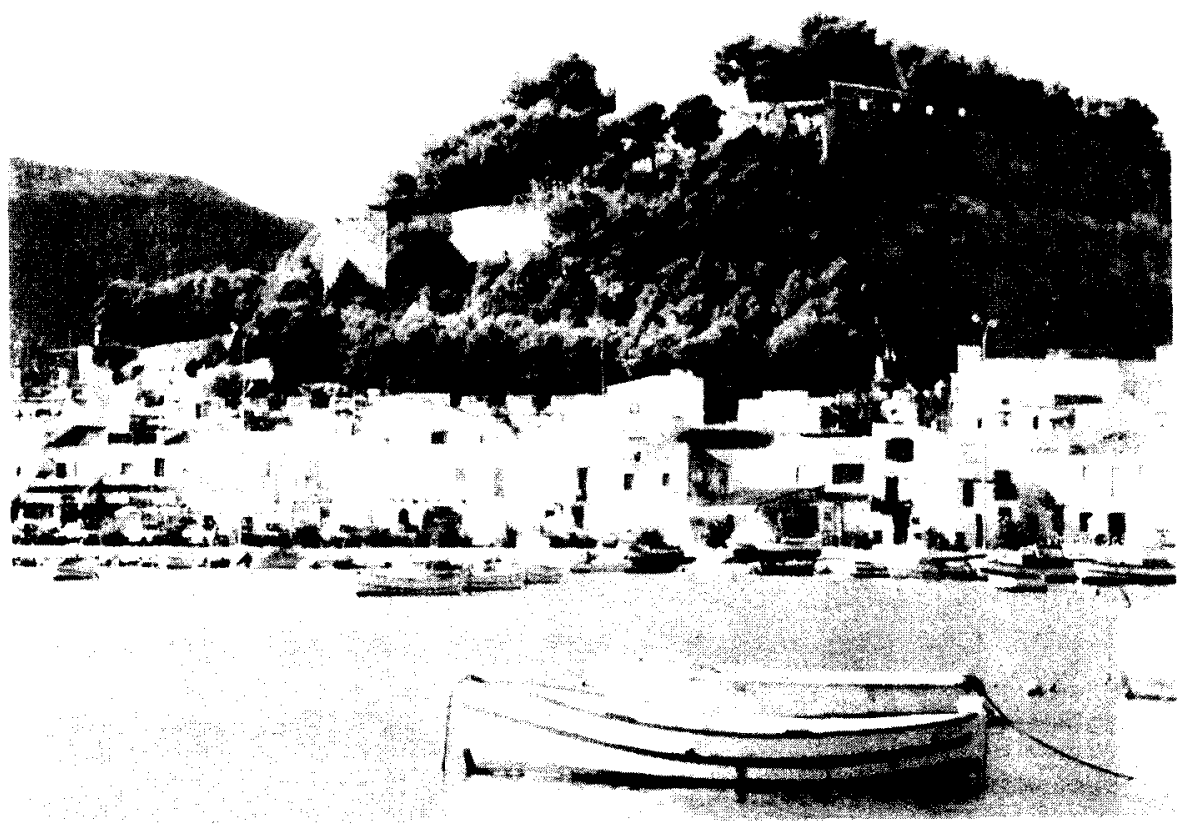

* Profesor de Enseñanza Secundaria. 
ciudad para adaptarse a unas circunstancias económicas y sociales, lo cual ha ido provocando una transformación en sus actividades y funciones.

Por lo que respecta a su situación, Denia se encuentra en el extremo N.E. de la provincia de Alicante con las siguientes coordenadas:

Latitudes N: 38 44' 15" y 38 52' 48"

Longitudes $E: 338^{\prime} 50^{\prime \prime}$ y 3 51' 25"

Con una superficie de $66 \mathrm{~km}$, resulta una densidad de 415,5 hab. $/ \mathrm{km}$.

Tiene dos zonas claramente diferenciadas, la llanura del Marquesado, al N. y N.O. y al S. el macizo del Montgó ( 753 m.) que, cuando penetra en el mar, forma el cabo de S. Antonio. Sus vertientes N. y O. pertenecen a Denia.

En la parte llana se encuentran los promontorios de El Gavilá $(29 \mathrm{~m}$.) y el Cerro del Castillo $(58 \mathrm{~m}$.). Este último está dentro de la ciudad y como su nombre indica es donde se encuentra el castillo, de donde parte la creación de la ciudad medieval. Por el N. la costa es suave y arenosa, con las playas de Las Marinas, Bovetes y Deveses, mientras que por el $S$. es escarpada, formando pequeñas calas en zonas como Las Rotas, Campusos,...

Las zonas O y S.O. son las más accesibles y donde se practica la agricultura, ya que tanto al N. como al S. está rodeada de marismas, el Marjal y el Saladar, respectivamente. Este último forma una pequeña depresión entre el monte del Castillo y la zona escarpada de las Rotas, continuación del macizo del Montgó.

Su emplazamiento está relacionado directamente, pues, con su fundación, es decir, su creación corresponde a una función de defensa y control del territorio.

\section{ESTRUCTURA DEMOGRÁFICA DE DENIA}

A la hora de estudiar este aspecto, analizaremos los datos proporcionados por el Padrón municipal, así como los obtenidos por el Instituto Valenciano de Estadistica (IVE), Instituto Nacional de Estadística (INE) y la Cámara de Comercio. Todos ellos nos proporcionan una composición de la población de Denia y, de esta forma, podremos comprender el desarrollo del paisaje urbano y ver como la morfología de la ciudad está relacionada con la evolución social de la que ha sido 
objeto y que ha supuesto una transformación de la estructura de la misma.

En líneas generales la población de Denia experimenta un gran crecimiento en lo que va de siglo (fig. 1), duplicando su índice en este período. Sin embargo dicho crecimiento no ha sido homogéneo observándose dos partes claramente diferenciadas, una primera que corresponde hasta la década de 1960, en donde se produce un estancamiento e incluso descenso en el índice de crecimiento de la población, debido a diversos factores como pueden ser la decadencia de la pasa, que comenzaria en 1913, debido a la plaga de la filoxera, con la consecuente crisis económica y pérdida de población por la emigración

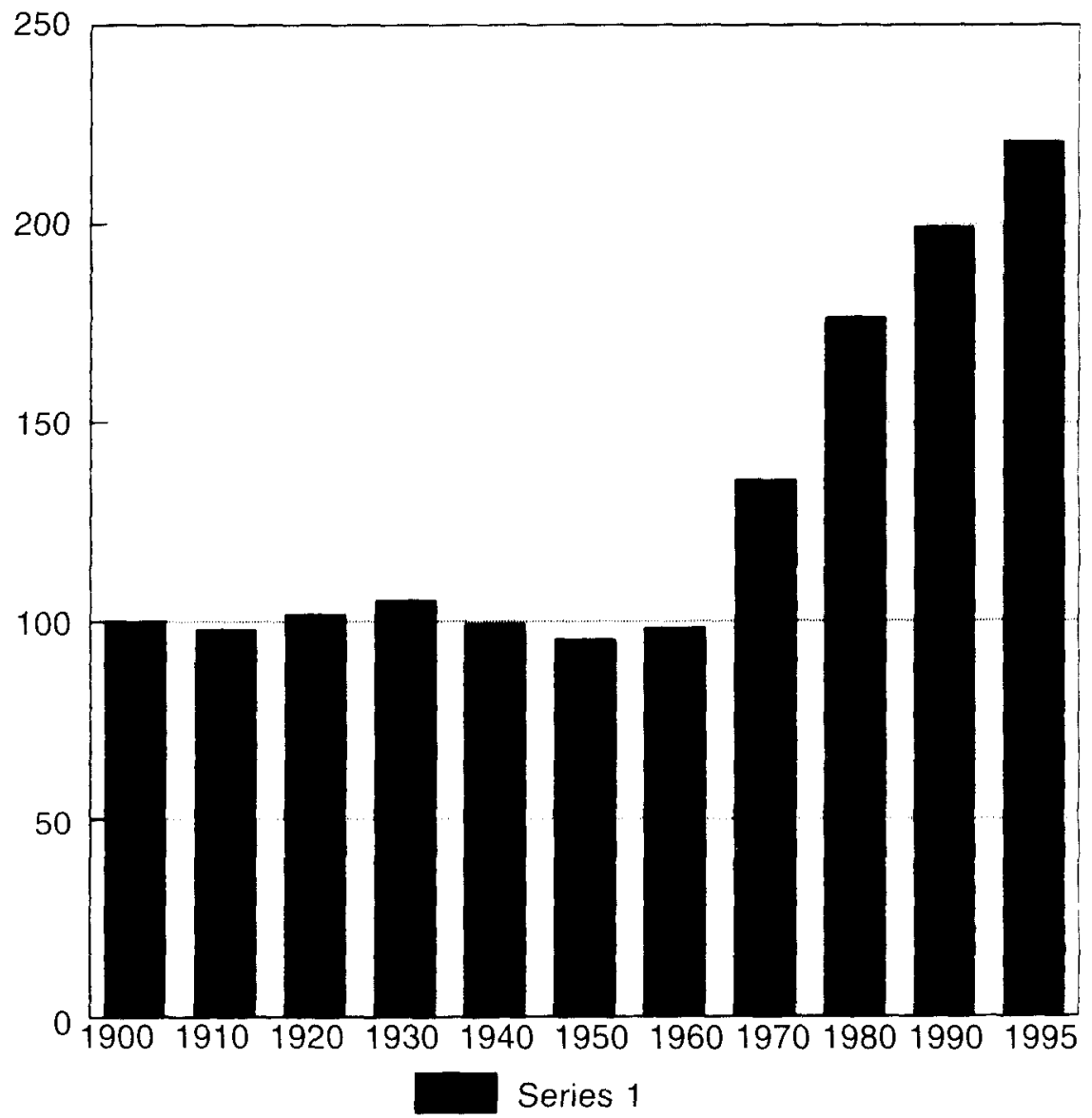

Fig. 1. Evolución de la población de Denia, 1900-1995. 
que ello provocaría, la epidemia de gripe de 1918 y, sobre todo, la guerra civil y la postguerra. La guerra contribuyó a aumentar la mortalidad y disminuir la natalidad y en la postguerra, las malas condiciones económicas de la población hizo que en la década de los años 50 , con el despegue económico de países europeos, se produjera un éxodo significativo de importantes contingentes de población a estos países en busca de mejores condiciones de vida, lo cual contribuyó, de forma directa e indirecta a una disminución o estancamiento de la población. La salida de emigrantes a Europa supuso privar de mano de obra joven a la ciudad e impedir que la natalidad creciera.

A partir de la década de los años 60, la población de Denia experimenta un considerable aumento, debido al elevado contingente de población que inmigra, procedente de las regiones más desfavorecidas de la peninsula (Andalucía, La Mancha,...), del interior de la misma provincia $e$, incluso, por la vuelta de parte de aquellos emigrantes (fig. 2).

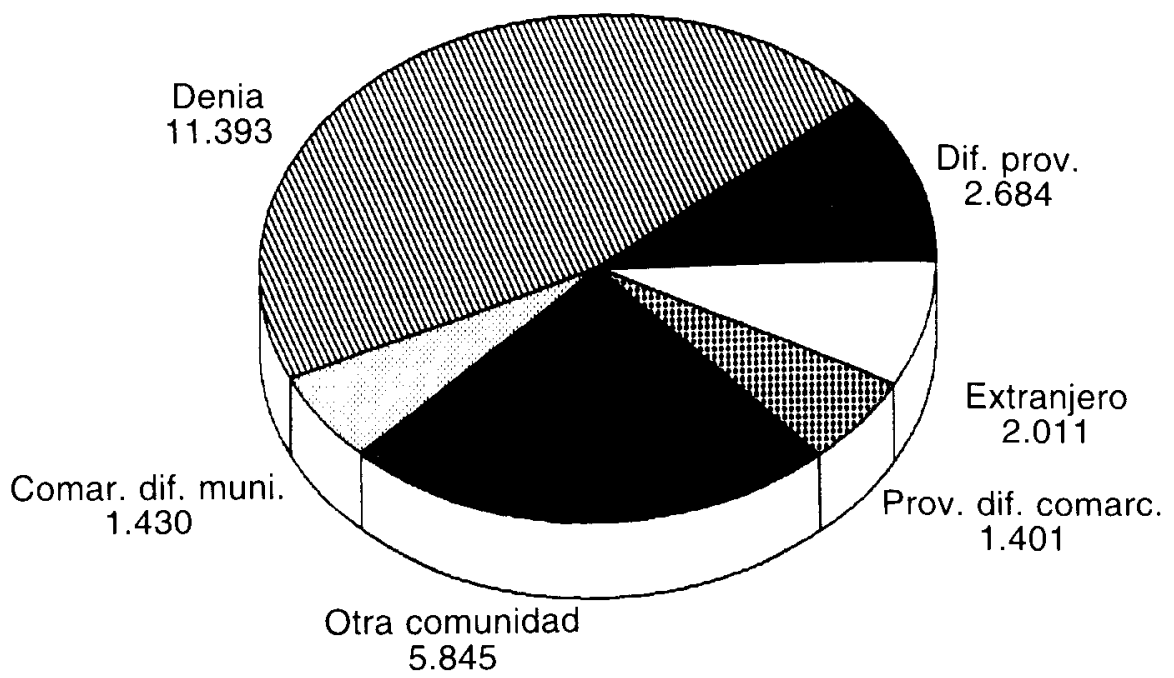

Fig. 2. Lugar de nacimiento de la población de Denia.

El auge turístico experimentado en las costas de la Comunidad Valenciana a mediados de los años 60 , supuso una fuerte demanda de puestos de trabajo, sobre todo, en el ramo de la construcción. La cualificación de estas gentes era, por lo general, baja. 
Por otra parte, el proceso de terciarización, determinado por el auge del turismo, ha conllevado también la llegada de otros grupos de población con mayor cualificación, para ocupar puestos de trabajo de mayor responsabilidad o los propios inversores, que movidos por la prosperidad de la región se apresuran a venir para construir en esta zona. Todo ello permite explicar el hecho de que la población de Denia haya duplicado su indice de crecimiento en 1995 con respecto a principios de siglo.

De esta forma, podemos determinar que su estructura demográfica ha sido consecuencia, no sólo de su crecimiento natural sino, sobre todo, de la inmigración que, por el hecho de tratarse de gente joven, en edad de procrear, contribuyó, además, a un mayor crecimiento de la población.

\section{La composición de la población por sexos y edades}

Es el resultado del dinamismo y evolución de la población a tenor de las circunstancias económicas y de la propia situación de la ciudad. En la pirámide de población correspondiente a 1991 (fig. 3) podemos

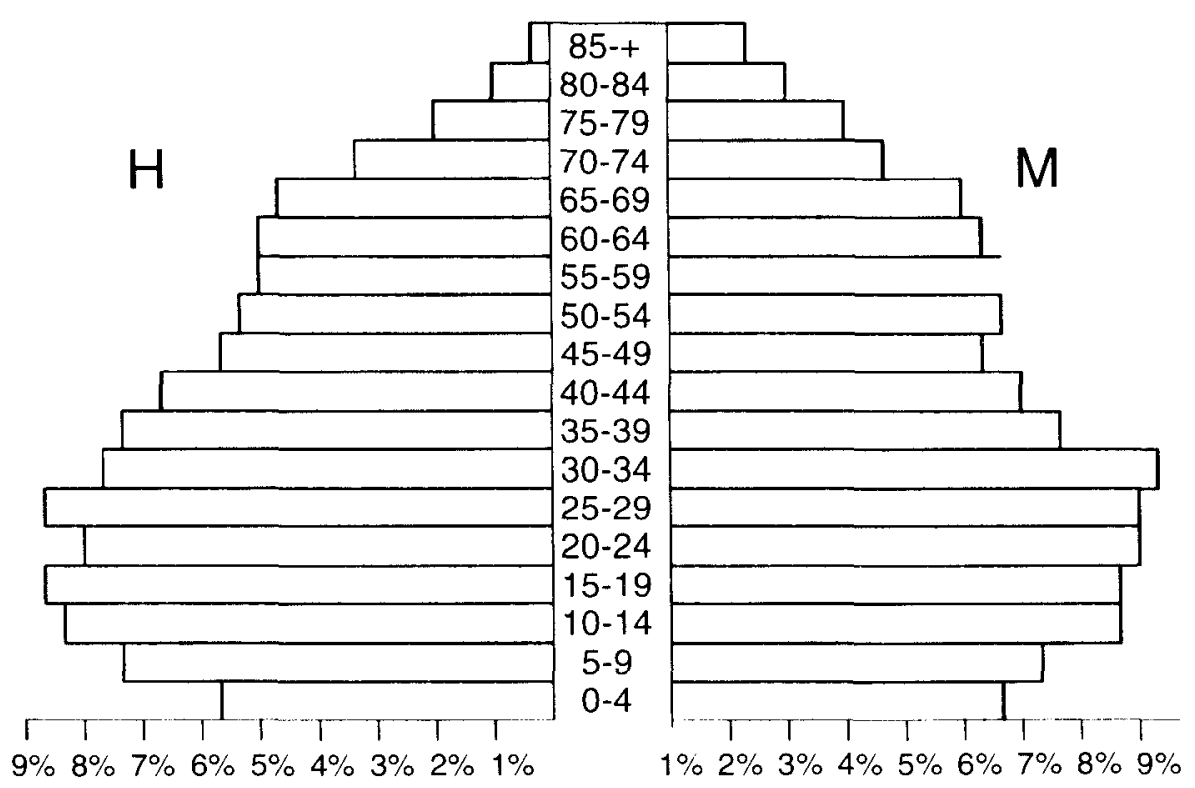

Fig. 3. Pirámide de población de Denia, 1991. 
apreciar cómo el grueso de la población corresponde a los grupos de edades comprendidas entre los 15 y los 55 años, que corresponden a los hijos y nietos de los primeros inmigrantes que llegaron en la década de los años 60 , lo cual contribuye a que exista un importante contingente de población joven, ya que la tasa de natalidad ha sido elevada hasta ahora.

La guerra y la emigración de los años 50 provoca una sensible disminución de la población masculina vieja, además de la mayor esperanza de vida de la mujer.

Por lo que respecta a los grupos más jóvenes, se aprecia una sensible disminución, significativamente acentuada entre los primeros años, debido a la progresiva disminución de la tasa de natalidad en los últimos años, alcanzando en 1994 el 16,55\%, lo que demuestra que el tamaño de la familia ha cambiado considerablemente, siendo cada vez más frecuente las parejas con un solo hijo o sin hijos, especialmente si los dos trabajan y tienen un cierto nivel cultural no ocurriendo todavía asi entre las clases socialmente más bajas, donde el número de hijos es mayor, lo que explicaría la todavía no muy baja tasa de natalidad (fig. 4).

Entre los grupos de población más vieja, todavía existe un importante contingente de población, a pesar de las consecuencias de la emigración sufrida a principios de siglo, que determinó un crecimiento vegetativo negativo y de los efectos que la guerra civil llevó a cabo sobre la ciudad. Esto es debido a que, como se refleja en la fig. 2, el $8,12 \%$ de la población de Denia es extranjera ', de los cuales, el mayor porcentaje corresponde a personas mayores, que se han asentado en esta zona, porque les suponía tener un nivel de vida más elevado que en sus respectivos países y gozaban de un mejor clima.

La existencia de colonias permanentes de extranjeros de diferentes nacionalidades explicaria la importancia que este contingente de población tiene en la ciudad.

Por todo lo anteriormente comentado, podemos decir que la población de Denia es abierta, a diferencia de las zonas del interior, cuya población es cerrada y homogénea. Esto es debido a que en la estructura demográfica de Denia influye, de manera decisiva las inmigraciones de grupos muy heterogéneos, mientras el interior sólo depende de su propia evolución demográfica.

Padrón municipal 1994. 


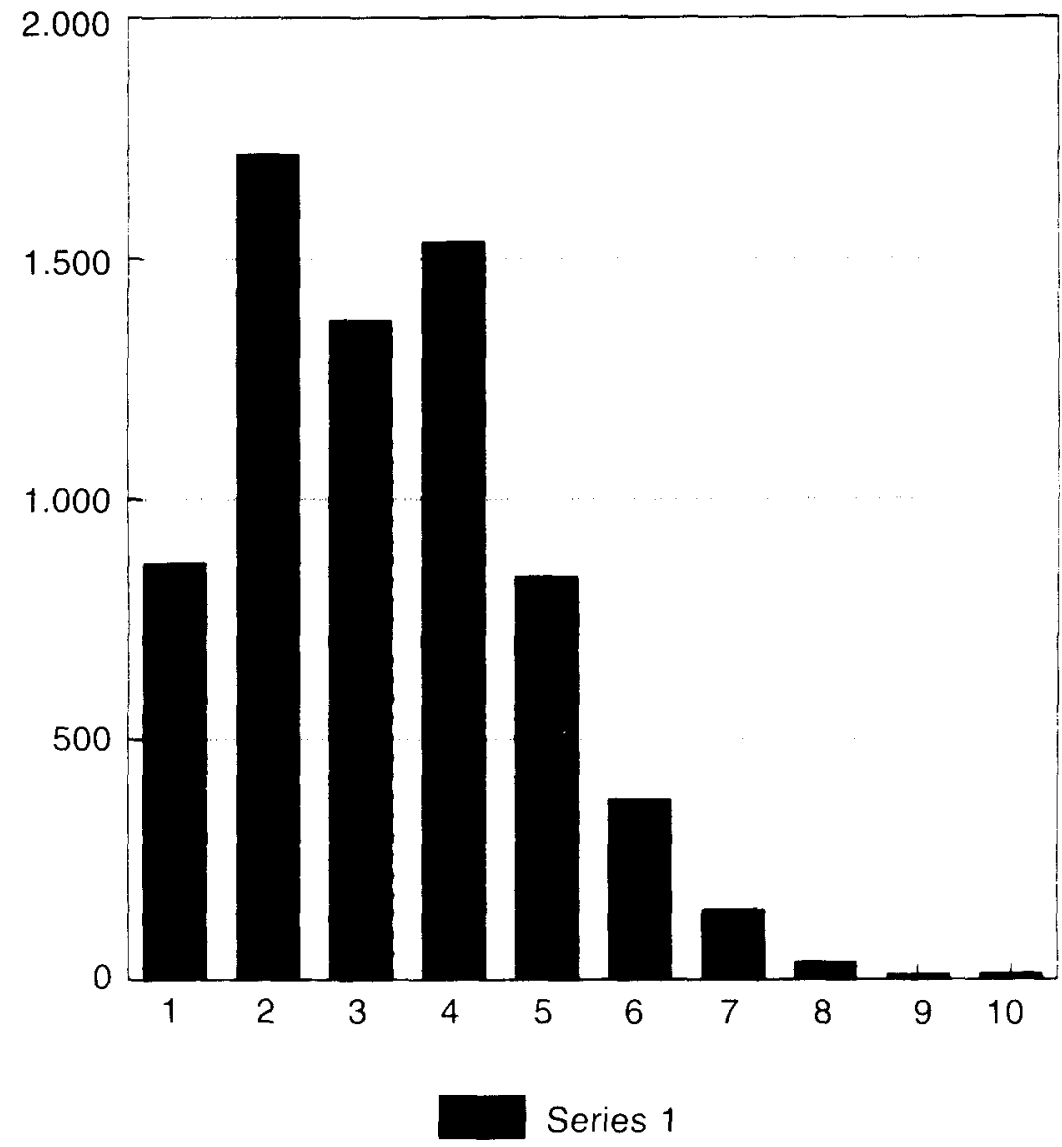

Fig. 4. Número de componentes en la familia

\section{Población activa}

A la hora de estudiar este aspecto, incluiremos a todas las personas que son mano de obra para poder producir bienes y servicios. Teniendo en cuenta esto, tenemos que considerar el contingente de población comprendida entre los 16 y 65 años, grupo que se ha determinado como potencialmente activo.

Esto supone que el $50 \%$ de la población de Denia es potencialmente activa, es decir, algo superior a la media nacional, que alcanza el $49,10 \%$. Sin embargo, el porcentaje de población realmente activa es del $33,62 \%$, 
inferior a la media nacional y significativamente muy por debajo de la totalidad de la Comunidad Valenciana ${ }^{2}$.

\begin{tabular}{llcc}
\hline & $\begin{array}{c}\text { DENIA } \\
(\%)\end{array}$ & $\begin{array}{c}\text { C. VALENCIANA } \\
(\%)\end{array}$ & $\begin{array}{c}\text { ESPAÑA } \\
(\%)\end{array}$ \\
\hline Población potencial activa & 50 & 52,60 & 49,10 \\
Población activa real & 33,63 & 60,04 & 48,71 \\
Población activa femenina & 11,06 & 20,19 & 17,29 \\
Población activa masculina & 22,56 & 39,85 & 31,42 \\
\hline
\end{tabular}

Fuente: Padrón municipal 1994, I.V.E. y Cámara de Comercio.

Hay que tener en cuenta que el volumen de población activa está intimamente relacionado con los aspectos socioeconómicos, culturales, movimientos migratorios y de la propia situación que existe en el mercado laboral, regido por la ley de la oferta y la demanda, y que actúa de forma, aún más desfavorable sobre la mujer, cuya cualificación suele ser más baja por haber tenido menores oportunidades y facilidades para su formación, lo cual le ha hecho estar relegada a las tareas del hogar.

Un hecho que podría explicar la diferencia entre el volumen de población potencialmente activa y activa realmente es que, aunque la edad de entrada en actividad esté fijada en los 16 años, ésta tiende a retrasarse, con el objetivo de buscar una mayor cualificación, para acceder a un mejor puesto de trabajo. Este hecho nos lo demuestra la fig. 5 con respecto a la población de Denia.

Estructura de la población activa según la actividad económica

Las variaciones en la actividad económica que experimenta la población de Denia a partir de los años 60 y 70 es el mejor indicativo para ver la transformación económica que tiene la ciudad. En los años 60 se observa claramente (fig. 6) como el sector económico primario era el predominante en la economia de la ciudad, donde sobresalen las personas que se dedican a la agricultura $(27,18 \%)$ y algo significativo, las dedicadas a la pesca $(2,05 \%)$. Por lo que respecta al sector industrial, hay que destacar

Los datos de la Comunidad Valenciana y de España corresponden al último trimestre de 


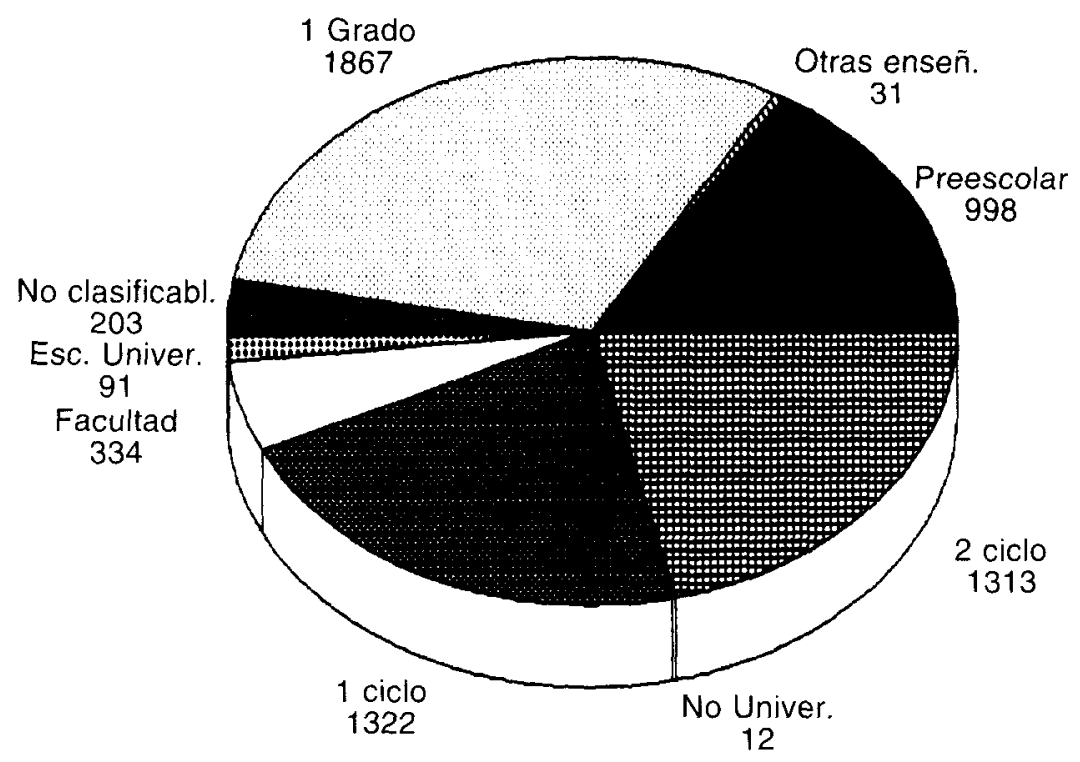

Fig. 5. Estudios en curso.

que sólo el $6,46 \%$ de la totalidad de este sector trabajaba en la industria, en la pequeña industria concretamente, mientras el resto, un $17 \%$, lo hacía en la manufactura ${ }^{3}$.

En la construcción se aprecia ya las consecuencias del boom turístico y fue el sector que acogió, en un principio, a la mayoria de los inmigrantes que llegaron a esta ciudad en la década de los años 60.

A partir de entonces, la agricultura pasaria a ser una actividad secundaria en el contexto económico de la ciudad, urbanizándose algunas de las tierras más productivas y la ampliación de la zona urbana sería necesaria para acoger a estos contingentes de población inmigrante, con lo cual el desarrollo del sector de la construcción sería un hecho evidente.

El sector servicios empezaba a despegar, iniciando un proceso de crecimiento muy acelerado.

Así pues, el cambio producido por el sistema económico ha supuesto una transformación de las actividades y funciones de la ciudad.

Fuente: Anuario de la Comunidad Valenciana. 


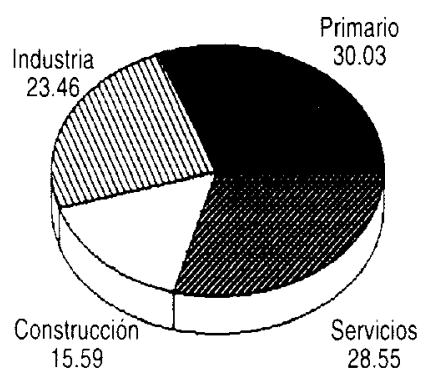

DENIA 1970

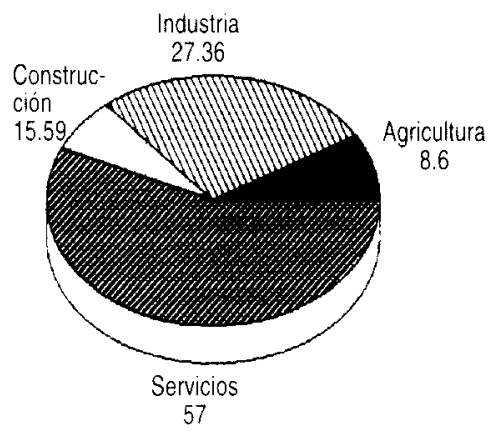

C. VALENCIANA 1993

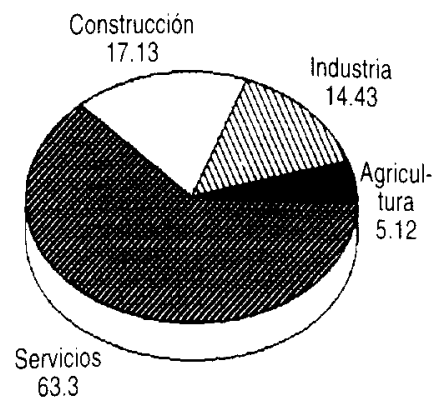

DENIA 1991

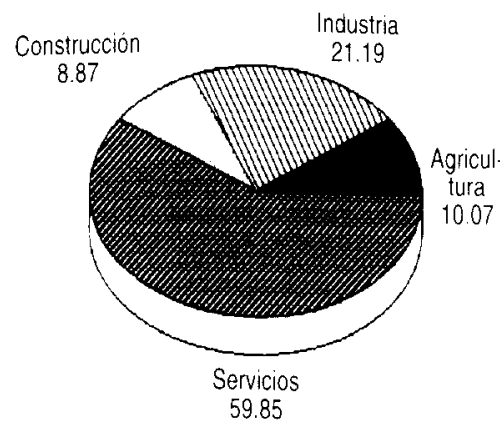

ESPAÑA 1993

Fig. 6. Actividad por sectores económicos.

El paso de la preponderancia de la actividad agricola a la de servicios ha afectado, no solamente a la estructura de los sectores económicos de la población, sino que también ha conllevado un cambio en la morfología de la ciudad, cambiando el paisaje de la misma y la aparición en las zonas periurbanas de áreas residenciales e industriales.

Como podemos apreciar en la fig. 6 el sector servicios es la actividad más importante, actualmente, de la población de Denia, con un $63,30 \%$ del

Fuente: I.V.E y Cámara de Comercio. 
total de la población activa ${ }^{4}$, superando significativamente al resto de los sectores económicos debido a que el proceso de terciarización ha aumentado considerablemente en los últimos años, afectando a la mayoría de la población, no sólo por el desarrollo del turismo, sino también por otra serie de factores decisivos en la economía de la ciudad, como son nuevos servicios en el campo de la educación, sanidad, ocio, la burocratización del sector secundario,...

Sin embargo, podemos también apreciar que se desarrollan todas las actividades incluso las agrícolas, con una importante producción de agrios, que comenzaría a principios de siglo, a medida que desaparecía la elaboración de la pasa, aunque en menor proporción que los sectores secundario, terciario y cuaternario.

Con respecto a la pesca, aunque su incidencia en la economía de la ciudad, es significativa y nos demuestra que la tradición pesquera, producto de la cultura romana, continúa. Vestigios de ello son las almadrabas encontradas, muestras de la importante industria de salazón que existió hasta el siglo xvIII. Sin embargo, actualmente, su peso económico no es decisivo en el contexto económico global.

La industria existente es, fundamentalmente, la manufacturera, como la destinada al juguete, aunque toda ella, hoy en día, está en crisis.

Por consiguiente, podemos decir que en la gran variedad de actividades que existen en esta ciudad, cabria afirmar que, fundamentalmente, son las actividades básicas las que se desarrollan, entendiendo como tales, las que proporcionan bienes y servicios al exterior y el porcentaje, como vemos, supera al nacional.

También observamos cómo, en lo que se refiere al resto de sectores, la construcción también supera significativamente al total de la Comunidad Valenciana y España, estos dos últimos más similares. Por el contrario, el sector industrial es claramente inferior, así como el referente a la agricultura.

Cabe, pues, para concluir, reiterar cómo el peso de la economía en Denia está basado en el sector terciario, por el peso decisivo que el turismo ejerce en la ciudad y esto conlleva una nueva morfologia urbana, en respuesta a este sector.

\section{La estructura profesional}

Está intimamente relacionada con los sectores de actividad económica. De esta forma podemos apreciar cómo las profesiones que predominan están vinculadas con el sector económico preponderante en la ciudad, es 
decir, el terciario (fig. 7). Asi pues, casi el $60 \%$ de las profesiones pertenecen a este sector, existiendo una gran diferenciación profesional que está en relación con una diferenciación de los niveles de vida, dependiendo de la cualificación personal de cada uno. El hecho de que los mayores porcentajes pertenezcan a la rama de administrativos, comerciantes y servicios vinculados con la hostelería y sólo el 1,92\% sean directivos nos demuestra que la cualificación suele ser baja y que son las actividades preponderantes en esta ciudad ${ }^{5}$.

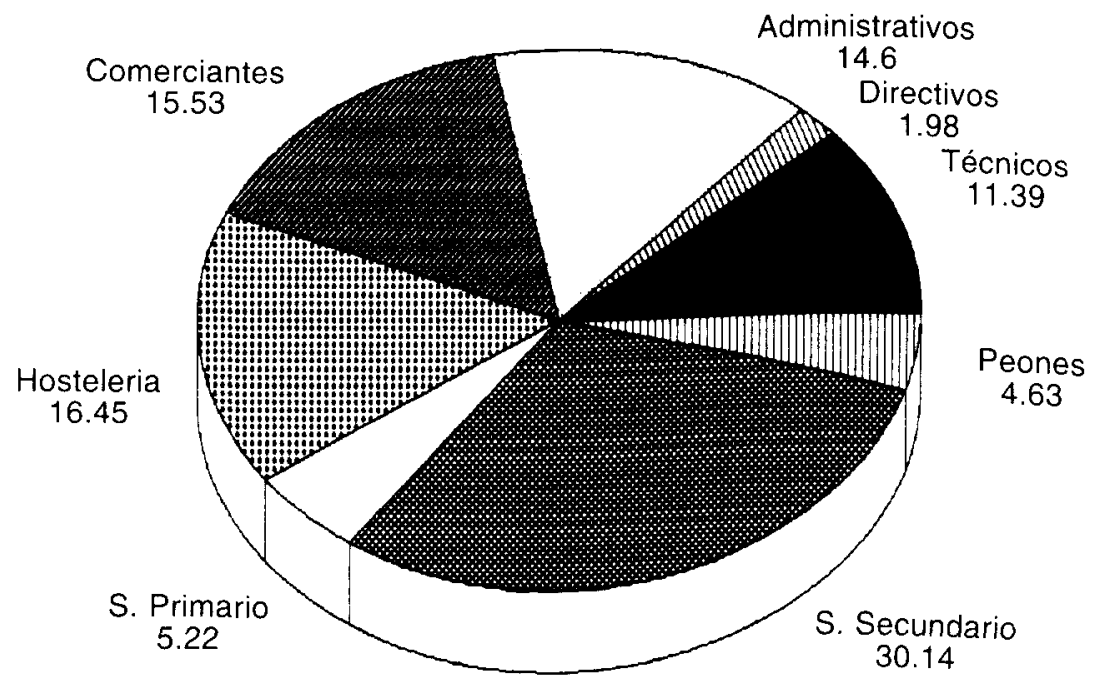

Fig. 7. Profesiones Denia 1991.

La existencia y apertura de un gran número de bancos y Cajas de Ahorros es otro índice de la estructura profesional de la población de Denia.

También el desarrollo de nuevos servicios en el campo de la educación, sanidad,... ha sido necesario, y esto ha supuesto que el $11,39 \%$ de la población sean profesionales, técnicos, etc.

Hay que destacar, por último, cómo la construcción, industria y transportes siguen siendo también actividades importantes en la ciudad. Por lo que respecta a esta última ha crecido considerablemente. El mayor número de líneas de comunicación con los pueblos de alrededor, así como con muchas ciudades, con el objetivo de facilitar el desarrollo del turismo ha su-

5 Fuente:I.V.E. 
puesto un crecimiento de las personas empleadas en transportes, incluyendo también aquellos transportes que no son sólo de personas, sino de mercancías y que responden a las demandas necesarias de la ciudad.

En to referente a la estructura profesional femenina hay que señalar cómo en las profesiones administrativas, comerciantes y de hostelería, el porcentaje de mujeres es algo superior al de los hombres ${ }^{6}$.

\section{Situación profesional}

Con respecto a la SITUACIÓN PROFESIONAL (fig. 8) vemos que la mayoria de la población es asalariada, representando el $72,71 \%$ del total ${ }^{6}$. Esto es un hecho normal, propio de las sociedades capitalistas, donde existen cada vez más trabajadores asalariados. En cuanto al número de empresarios, lo más frecuente es que lo sean sin trabajadores ajenos, siendo los miembros de la familia los que ayudan en el negocio. De esta forma también se explicaría que sólo el $5,34 \%$ de las mujeres sean empresarias, pues entre sus funciones estaría el ayudar, de forma no remunerada ni contable a la economia familiar ${ }^{6}$.

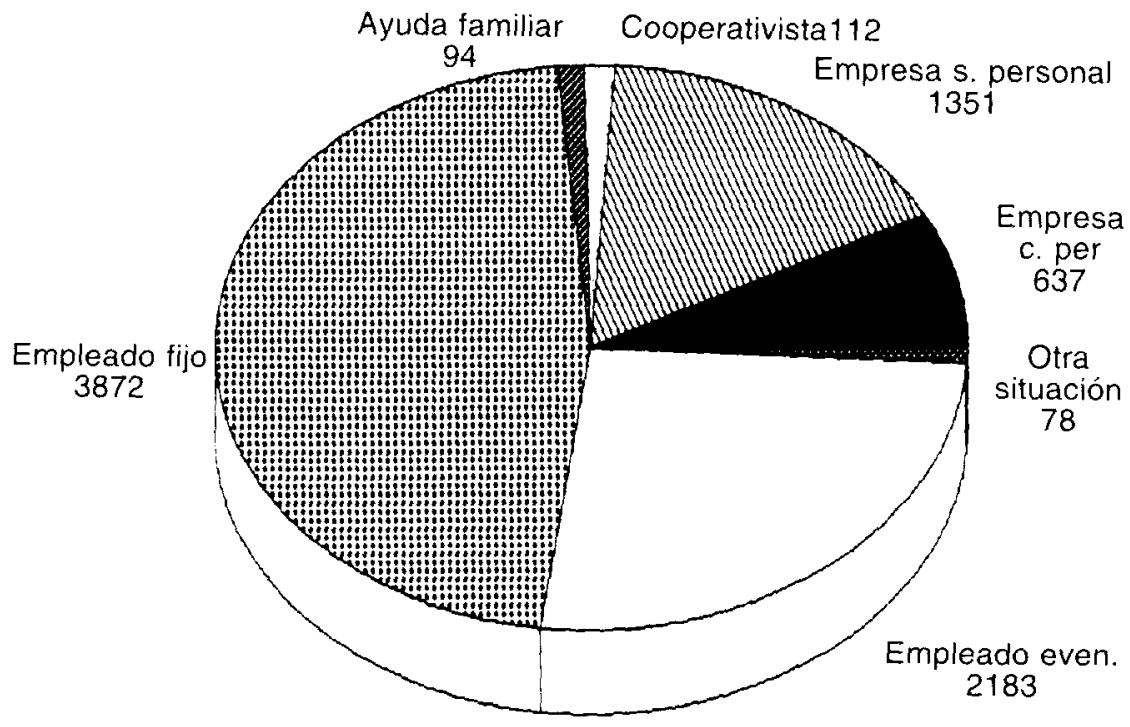

Fig. 8. Situación profesional Denia 1991.

6 Fuente: I.V.E 


\section{EVOLUCIÓN URBANA DE DENIA A LO LARGO DE SU HISTORIA}

No pretendemos hacer un estudio exhaustivo sobre el desarrollo urbano de la ciudad de Denia a lo largo de su historia. Nos hemos limitado a hacer un análisis de los estudios realizados con mayor profundidad sobre este aspecto concreto. Nuestra labor ha tratado, sobre todo, de estudiar el impacto que la ciudad ha sufrido a raiz del boom turístico producido en la década de los años 60 y que supuso una transformación cuantitativa y cualitativa de la morfología de la ciudad.

\section{Origenes}

Lo que sí podemos afirmar es que, salvo la existencia de restos del Calcolítico, el pasado de Denia se remonta a la cultura ibérica, por los establecimientos hallados en el Montgó. El más antiguo data del siglo IV a. C., ubicado en la Punta de Benimaquia y compuesto por un recinto amurallado, con cinco torres de planta cuadrada. Otro, del siglo III a. C. está en el Pico del Águila.

Sobre la traída y llevada colonia griega de Hemeroscopión no hay datos fidedignos.

Lo que es posible que hubiese serian contactos comerciales, pero en épocas más tardias ?

Lo que sí parece haberse demostrado es la existencia de una fortificación, posiblemente en la cima del castillo, utilizada por los ejércitos de Sertorio como zona de avituallamiento, debida, sobre todo, a la importancia del puerto.

Es a partir del siglo ॥ cuando la ciudad romana, Dianium, ya en el llano, concentrada en la zona, hoy denominada Huerto de Morand, al N. del castillo, adquiere la estructura urbanística característica de las ciudades romanas. Estructurada en torno a dos importantes vías -el cardus y el documanus-, que conformaban un trazado reticular del tipo de las centuriaciones. El cardus seguiría la dirección N-S que enlazaría el camino viejo de Pego a Denia, posiblemente el acceso de la vía de Augusta a Denia, mientras el decumanus, con dirección E-O, uniría los núcleos de población existentes con el puerto, ya que la población no sólo se concentraba en la ciudad, sino que había también un importante hábitat disperso, cuya riqueza principal provenía de la agricultura y de las almadravas. Este hecho nos lo corroboran los numerosos restos encontrados - cerámica,

\footnotetext{
7 Martin, Gabriela: “La supuesta colonización griega de Hemeroskopeion. Estudio arqueológico de la zona Denia-Javea". Valencia, 1968.
} 
ánforas, inscripciones funerarias- en la zona N.O. de la ciudad. Así pues, la ciudad en el Alto Imperio (siglos I-III) debía tener una acrópolis en el castillo y un desarrollo en el llano.

\section{La ciudad medieval}

Será con la descomposición del Califato de Córdoba y la consecuente aparición de los reinos taifas, en el siglo xl, cuando comience el explendor de Daniyya, ya que hasta el momento los asentamientos que se habian producido eran de bereberes, los cuales practicaban una economía básicamente agrícola y ganadera y, consecuentemente, el desarrollo urbanístico no se produjo.

Durante el gobierno de los reyes Muyahid y Ali Ibn Muyahid es cuando el reino taifa de Denia adquiere su máxima importancia, abarcando el sur de las comarcas valencianas y Baleares.

La ciudad árabe supone el origen de la ciudad actual, ya que ha cambiado de orientación con respecto a la ciudad romana que se había creado y desarrollado al N., mientras que, en este caso, la orientación es al S. del monte del castillo, resultando más ventajosa, pues permite estar más soleada y utilizar el monte para evitar el frío.

El crecimiento de la ciudad se experimenta de forma concéntrica y con respecto a su estructura cabe distinguir tres recintos: La Alcazaba o residencia real, El Albacar, con capacidad para acoger a un importante contingente de población, aunque estuviera despoblado, y los Arrabales, donde se concentraba la población.

Había, aún, otro recinto, amurallado, el Fortí, separado de la ciudad por el Riachol.

La descripción de Al-Idrisisi ${ }^{8}$ nos proporciona una idea de las características de la ciudad. Dice así: "Denia es una bonita villa marítima con un arrabal bien poblado. Está ceñida por fuertes murallas y estas murallas, del lado de oriente, han sido prolongadas hasta el mar con mucho arte e inteligencia. La villa está protegida por un castillo fuerte y rodeada de campos cultivados de viñedos y plantaciones de higueras. Muchos barcos acuden allí y también hay arsenales donde se construyen. De alli parten muchos navios que van a las regiones más lejanas y de allí también sale la escuadra en tiempos de guerra. Al mediodía de la villa hay una montaña redonda desde cuya cima se ven los montes de lbiza sobre el mar. Se llama Monte Câcón».

"Al-IDRISI: “El Idrisi y sus noticias sobre Denia", págs. 373-374, revista "El Archivo", vol I. 
A partir de 1076 el reino taifa de Denia es incorporado al de Zaragoza hasta su definitiva conquista y posterior repartición en 1244 con Jaime I, pasando a formar parte de las posesiones reales y señoriales.

Parte del vacío dejado por la población morisca fue sustituido por payeses mayorquines, pero el número de éstos, proporcionalmente, fue muy bajo.

Como consecuencia de las repoblaciones se crearía, posiblemente, un poblamiento disperso y la ciudad quedaría prácticamente deshabitada, ya que la población musulmana que permaneció fue relegada a arrabales fuera de la ciudad, las morerías. De la ciudad árabe sólo quedaba la morfología y el trazado de las calles.

Después de 1308, el núcleo de poblamiento queda dividido en dos partes: la Vila -antiguo Albacar, el castillo- donde se trasladarían los grupos sociales más importantes, y el Arrabal —antiguo Arrabal de tierradonde viviría el pueblo llano.

Después de pertenecer a la Corona de Aragón, el señorío de Denia, en 1431, pasaba a la nobleza castellana con la familia Sandoval. Serian, pues, los Marqueses de Denia los que detentarían el poder señorial hasta 1804 , año en que se incorporaría definitivamente a la corona, antes de la abolición total del régimen señorial.

A mediados del siglo XVI se produce un trasvase de la población de la Vila hacia el Arrabal, pues éste tiene calles más amplias y las casas son más nuevas. Ha habido, pues, una sustitución del espacio principal, las viviendas. A partir de ahora, el Arrabal se irá convirtiendo en la parte más importante del conjunto urbano, hasta el punto que, cuando Felipe III, después de la expulsión de los moriscos, le otorga el título de "Ciudad" (1612), el Arrabal, que ahora pasará a llamarse ciudad, obtendrá total supremacia sobre la Vila Vella (Ciudad Vieja). La ausencia de morerias iria unida a la construcción de los conventos de los franciscanos (1600) y de los dominicos (1604), conjuntamente con casonas y palacios.

El núcleo de población ocuparía, aproximadamente, la mitad de la superficie delimitada por las murallas, quedando libres importantes áreas en el N.E. y en el S. Todo ello delimitado por las murallas que pueden identificarse actualmente con las calles Ronda de las Murallas, Estrella, Barbacana, Quevedo y Diana, y abierto a través de dos puertas, la del Mar, al E, actual plaza del Pais Valenciano, y la de la Cruz, al O.

La puerta del Mar, permitía la salida al camino del puerto, rodeando el monte del castillo y coincide, actualmente, con las calles de La Mar y Fora Mur.

La puerta de la Cruz permitía la salida a los caminos que conducían a Ondara y Oliva. 


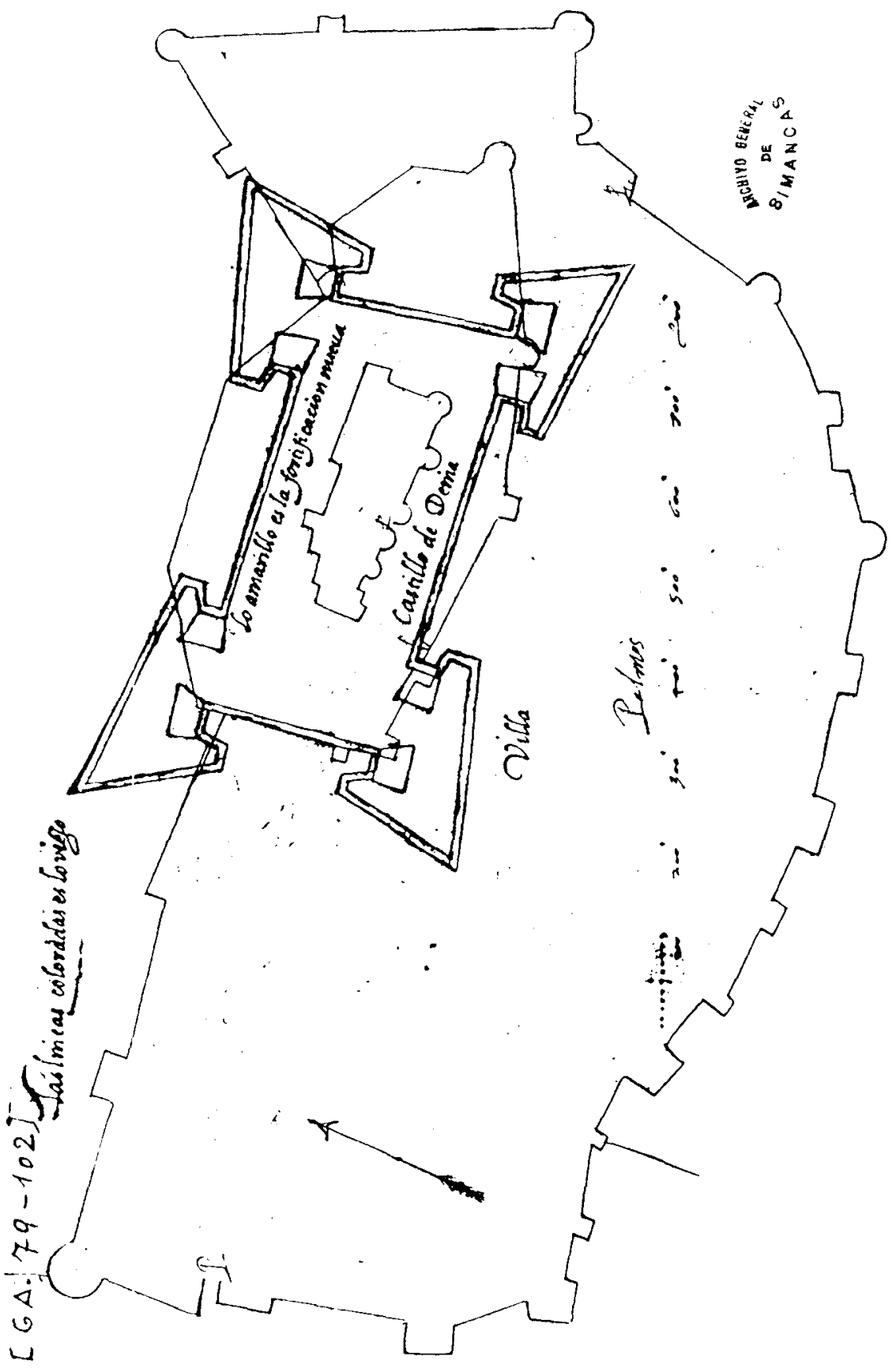




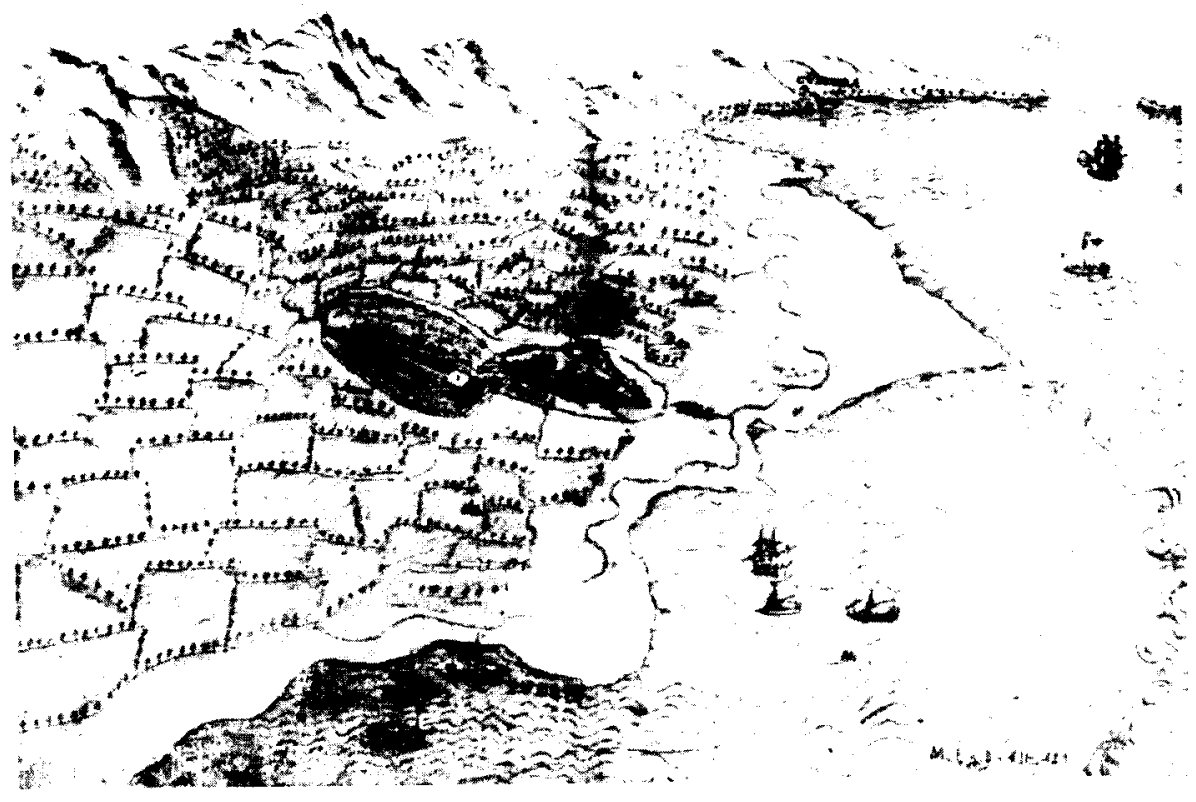

Plano en perspectiva de la Plaza de DENIA y de sus alrededores (S.f) Valencia, 30 de septiembre de 1575. Tinta y colores $573 \times 415 \mathrm{~mm}$. Con carta de Virrey de Valencia al Rey de la fecha anotada.

M.P. y D. VII-120; Guerra Antigua, legajo 79 (102).

La Guerra de Sucesión y el rechazo que la ciudad habia tenido a Felipe $\mathrm{V}$, con el consecuente apoyo al archiduque Carlos, - «Denia fue la primera ciudad de la corona de Aragón que proclamó a Carlos 111 y desconoció a Felipe $V$ " ${ }^{9}$, provocarian la destrucción de la ciudad y la casi total despoblación de la misma. El historiador Roc Chabás nos dice así: «A los horrores de tres sitios, a la destrucción de tantos edificios, a la pérdida de la parroquial, a la devastación del término, a la expatriación de la casi totalidad de sus habitantes y confiscación de sus bienes, a la abolición de sus venerandos fueros, sucedió el despotismo militar, la demolición de la Villavieja, las vejaciones continuas de los habitantes que volvieron a Denia, las contribuciones que cada día se les exigian,..." ${ }^{10}$. 


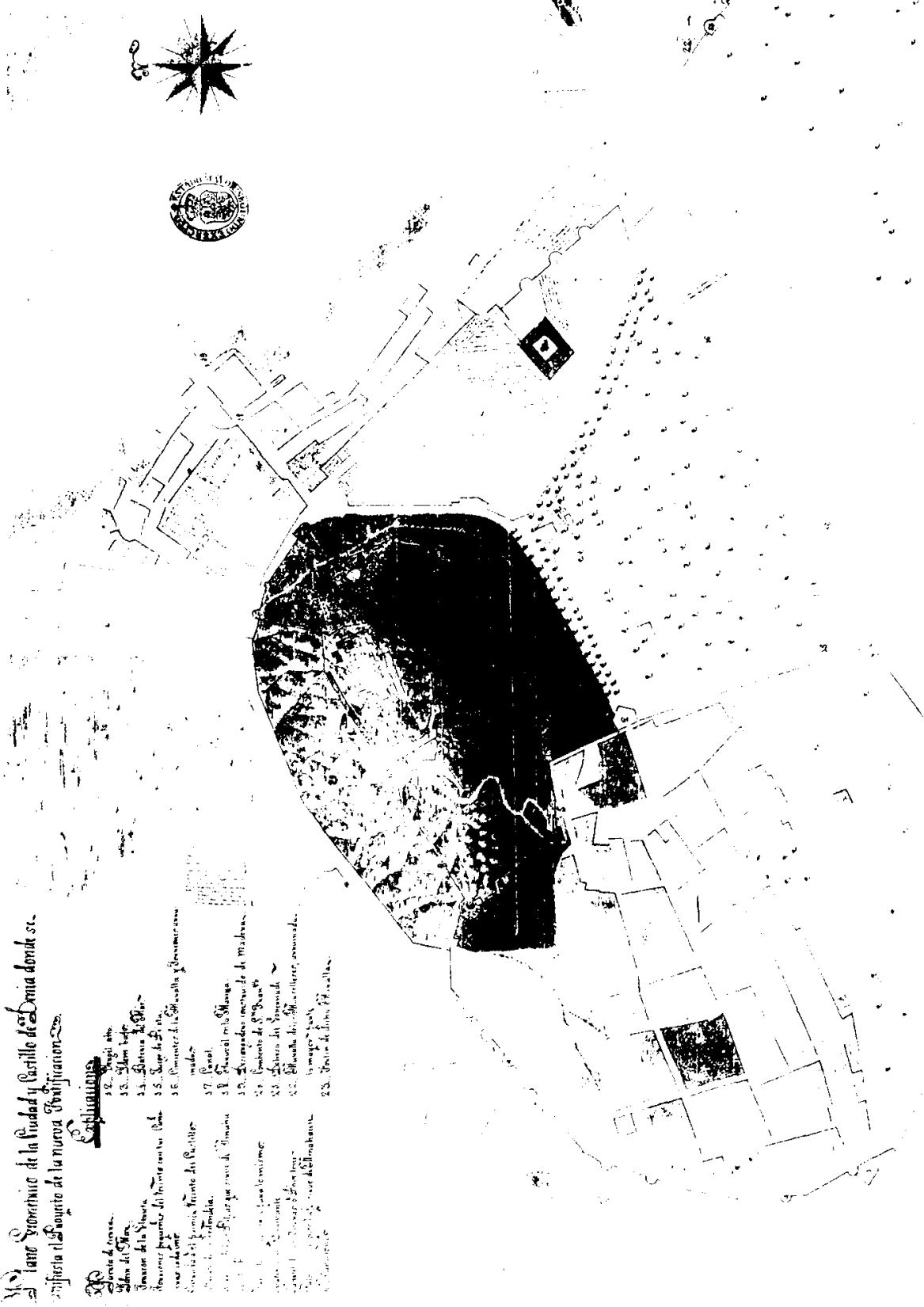


El puerto será factor decisivo para explicar la recuperación económica de la ciudad, hecho que se produce a finales del siglo xVIII, y el Arrabal del Mar se configurará, con la misma morfología que tiene actualmente, y será el mejor exponente del desarrollo comercial de la ciudad ${ }^{11}$.

Otro hecho que marcará el desarrollo de la ciudad es su incorporación a la Corona (1804) y la abolición del régimen señorial ${ }^{12}$, lo cual provocó la aparición de una burguesía liberal que sería la artífice, a lo largo del presente siglo, de los profundos cambios económicos y urbanísticos que experimenta la ciudad.
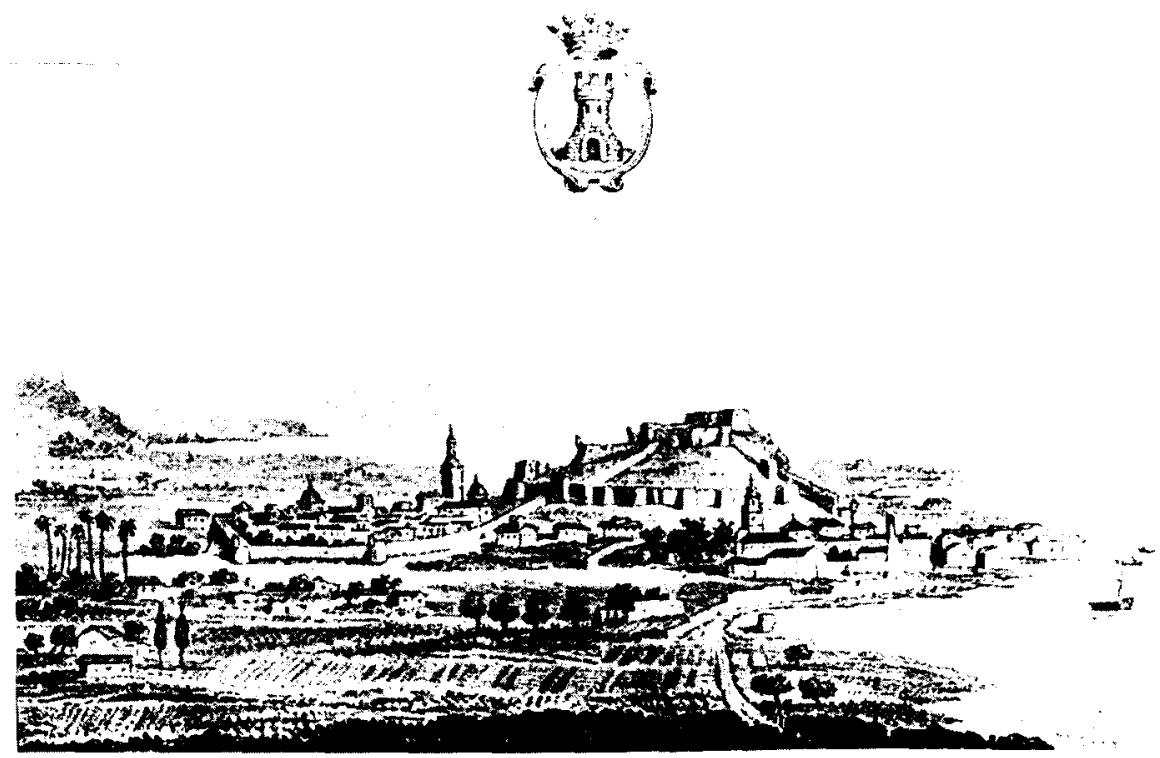

Foto tomada de la ciudad de Denia antes del derribo de las murallas. Fuente: Idem 3, pág. 229.

La ciudad desde el siglo xix hasta mediados del siglo $x x$

El siglo XIX marca un hito con respecto a todas las épocas anteriores. La aparición y desarrollo de la burguesía va a suponer una transformación urbana, hecho que se realizará de forma planificada, frente al crecimiento desorganizado que provocó la sociedad medieval y que dio origen a la Villa Vieja y los Arrabales. 
La apertura de nuevas calles rectilíneas, cortadas por otras, formando ángulo recto, las construcciones de casas, almacenes, ... contribuirian al cambio morfológico de la ciudad.

Un factor que contribuyó de manera decisiva al desarrollo de la ciudad fue el comercio de la pasa, desarrollado, sobre todo, con Inglaterra, durante más de un siglo, fue la causa de la riqueza y prosperidad de Denia.

La fabricación de la pasa, llevada a cabo desde los siglos XIII y XIV por los moriscos, que fabricaban el adzabid, continuó hasta el siglo XIX, que es cuando adquirió importancia. El cultivo del moscatel y la existencia del puerto fueron elementos decisivos para el desarrollo económico.

Fue un producto que movió el interés de agricultores, que explotaron al máximo sus propiedades, roturando, incluso, nuevas tierras, y el espacio rural se pobló de esplendidas villas, casas de labranza y riu-raus - cobertizos adosados a la vivienda rural, abiertos mediante arcos, donde se depositaba la pasa para protegerla de las inclemencias del tiempo-.

Almacenes, serrerías, fábricas de envases, se fueron creando y cambiando la morfología urbana, al mismo tiempo, que fue necesaria gran mano de obra, sobre todo femenina, pues su salario era más bajo, lo cual provocó un considerable aumento de la población. Un elevado nivel de vida por la prosperidad comercial que proporcionó el comercio de la pasa, fueron las causas de este rápido crecimiento de la población, que pasó de un indice 100 en 1860 a un indice de 175 en $1897^{13}$.

Este importante negocio hizo que Denia se convirtiera en una ciudad cosmopolita y una burguesía comercial se enriqueciera y llevara a cabo la transformación urbana de la ciudad.

El puerto de Denia conoció una actividad intensisima. Agentes, representantes y todo tipo de intermediarios se dieron cita en la ciudad, al mismo tiempo que se crearon los consulados de Francia, Inglaterra, Italia y EE.UU.

Hacia mediados del siglo XIX existen, pues, todos los síntomas de modernización y cambio estructural en la ciudad. A la Plaza Mayor desembocarían las calles más importantes y otras cercanas a ella, cuyos edificios son los de más carga social y arquitectónica: Loreto, Caballers, Mayor, ... Aparecen también los primeros paseos y alamedas, como la que discurría desde la puerta del Mar hasta el puerto, rodeando el monte del castillo, y que se bifurcaba en un camino que conducía al convento de $\mathrm{S}$. Antonio.

13 Fuente: Archivo municipal. 


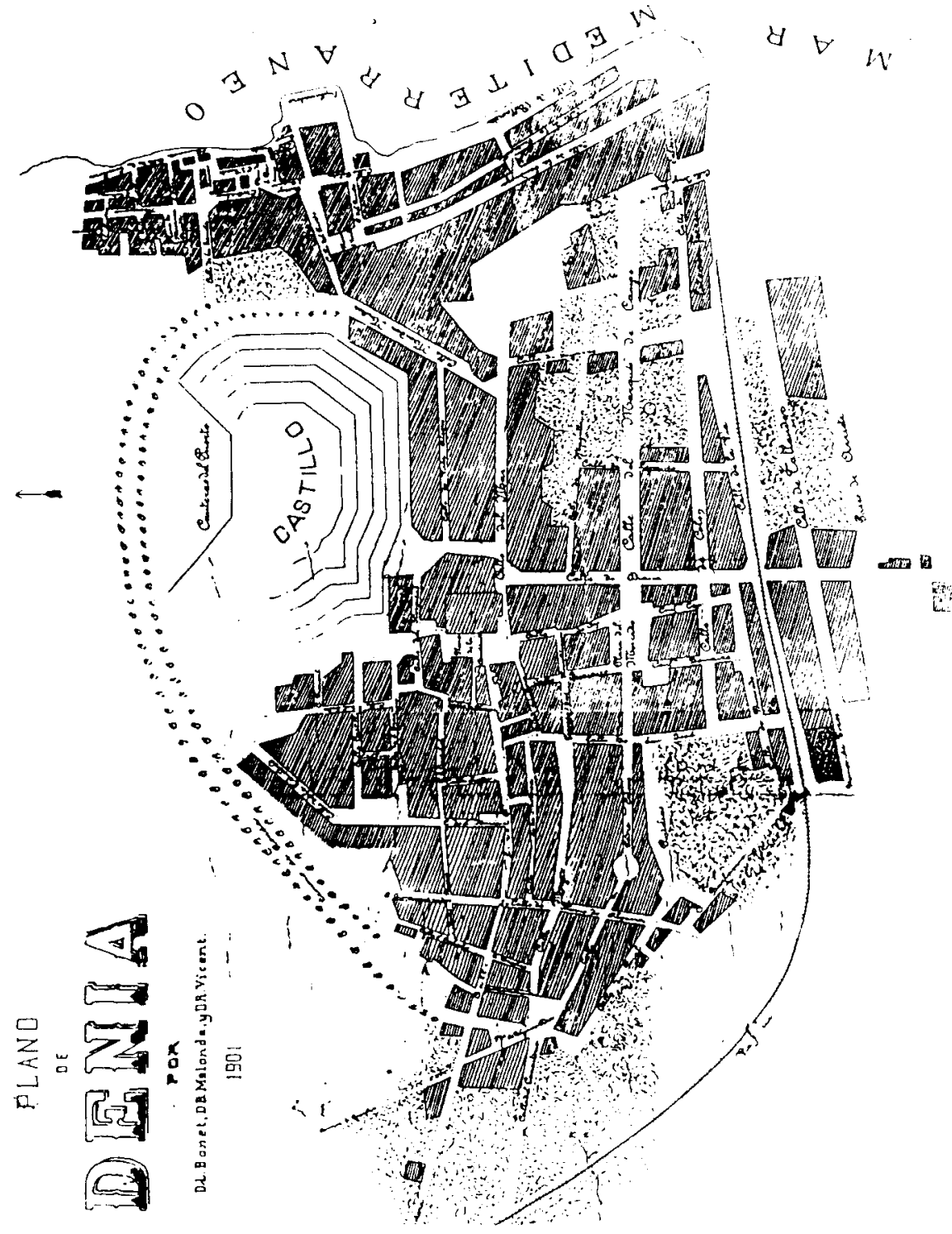


En la década de los años 40 se elaboran diferentes planos geométricos y surgen nuevas calles como Pare Pere.

En 1859 se dispuso el derribo y demolición de las murallas de Denia ${ }^{14}$, lo que serviria para acometer el ensanche de la ciudad, hecho que se produjo con el plano de Patricio Ferrándiz, pudiéndose articular la zona de crecimiento con las salidas de la ciudad.

Los materiales producidos del derribo de las murallas a lo largo de los siglos $\mathrm{XIX}$ y $\mathrm{xX}$, al igual que los alubiones del Montgó, sirvieron para colmatar la zona del Saladar y poder unir a la ciudad el antiguo recinto amurallado del Fortí, que estaba separado de ella por el Riachol (riachuelo).

Conjuntamente con las transformaciones urbanas, en los últimos años del siglo XIX se asiste también a una serie de innovaciones como son la entrada de las aguas potables, llegada del ferrocarril, teléfono, telégrafo, automóvil, ..., hechos que potencian y corroboran el desarrollo de la ciudad.

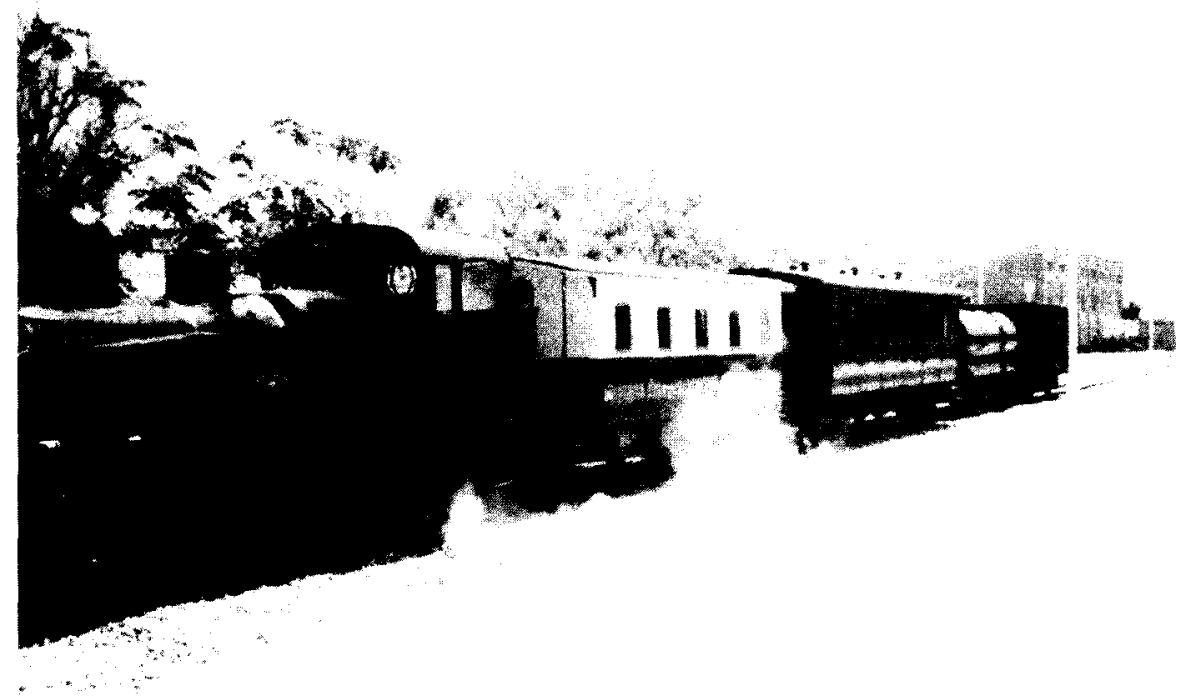

Ferrocarril de Denia.

14 Idem 3, pág. 459. 
En el nuevo siglo y, a pesar de que el desarrollo urbanístico va a disminuir, sobre todo a partir de la crisis de 1913 - por las causas anteriormente comentadas - se va a llevar a cabo la prolongación, desde la Glorieta, de la calle Pare Pere, dando lugar a la calle Marqués de Campo, situándose en el centro del casco urbano, uniéndolo con el puerto y convirtiéndose en el espacio más emblemático de la ciudad. Casinos, cafés, teatros, cabarets, bancos, hoteles, ... se levantarían a lo largo de lo que hoy es la mitad de este eje, que constituiría el centro de la vida activa de Denia. Su tamaño

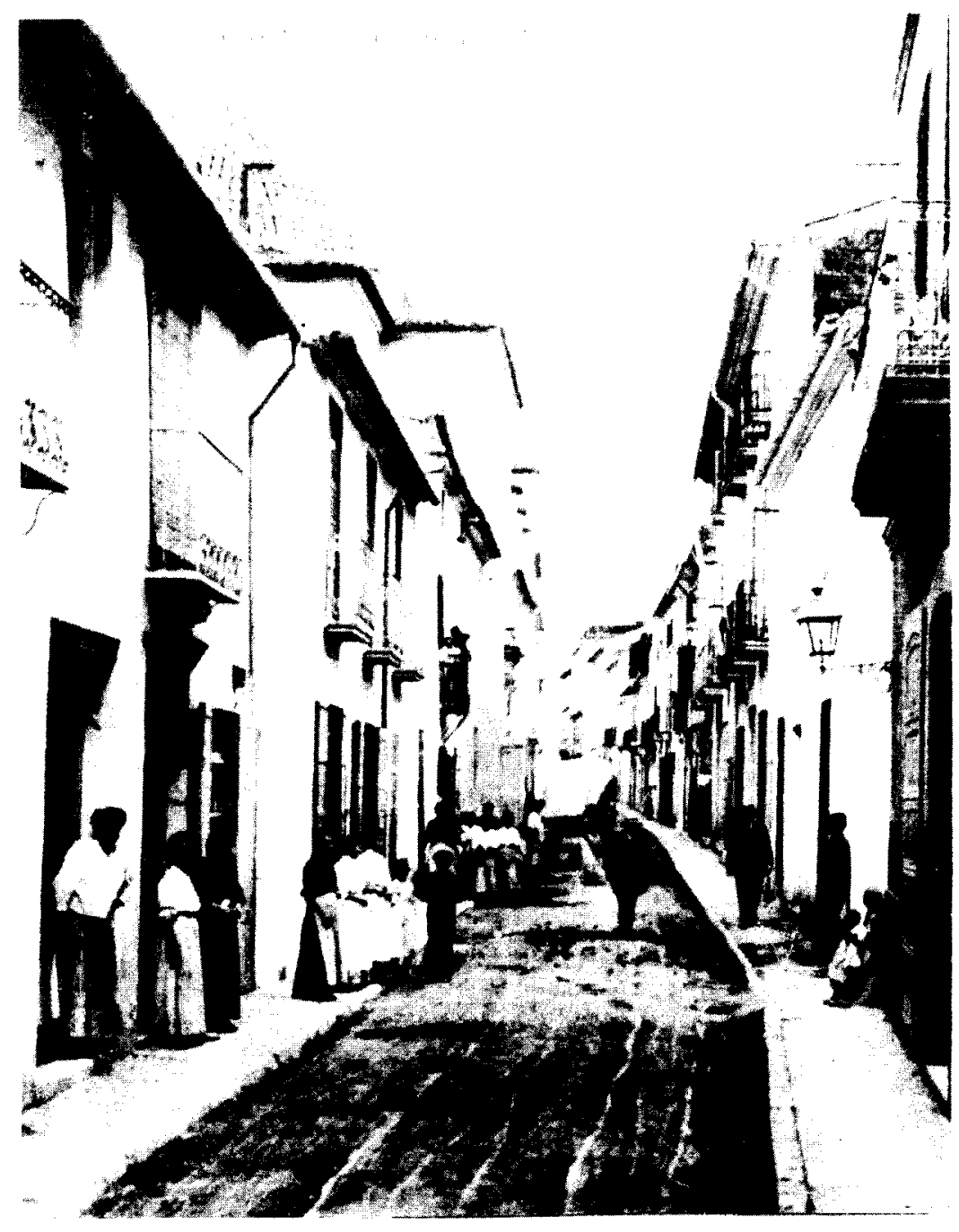

DENIA. Calle de Loreto. 


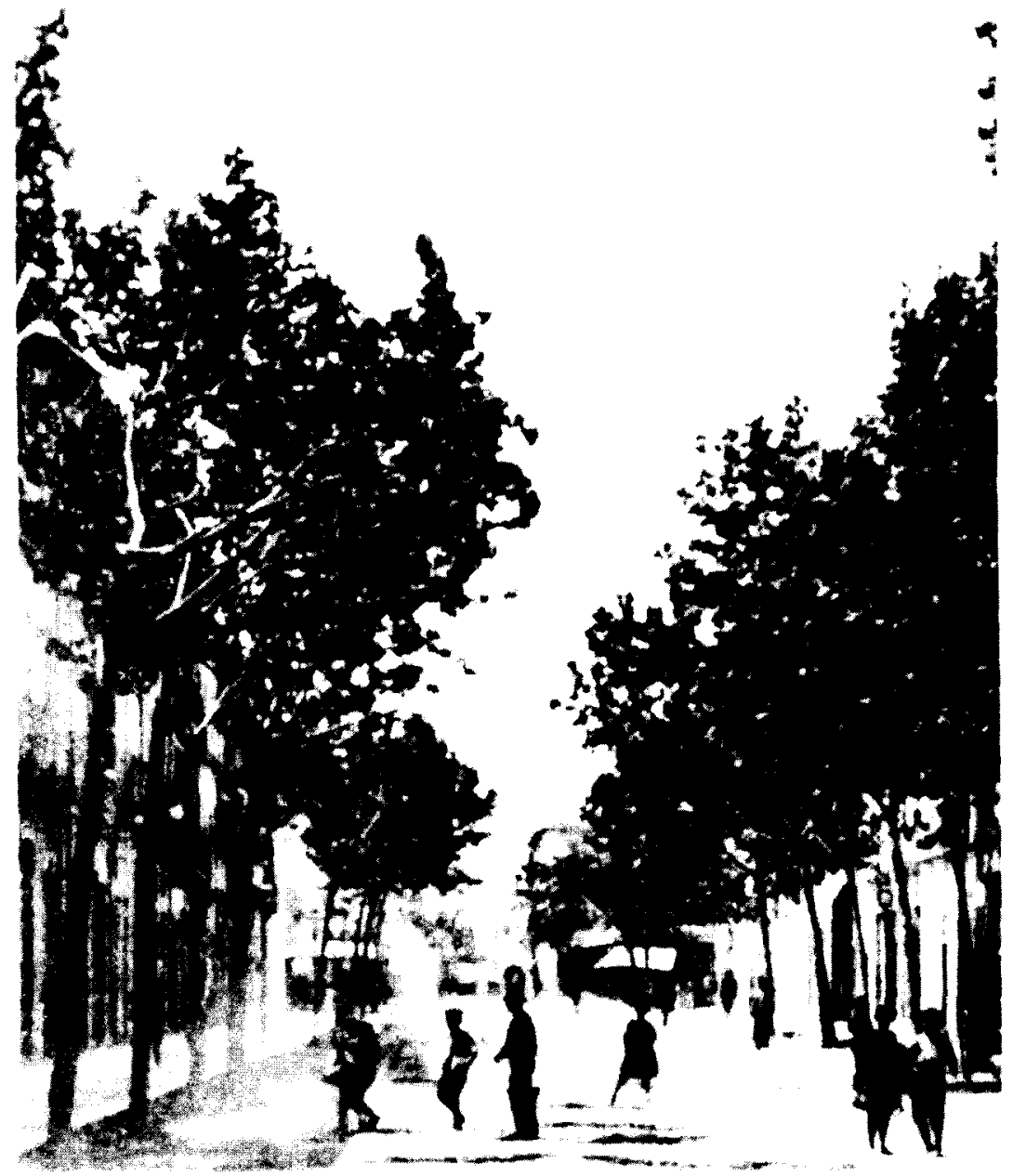

DENIA. Calle del Marqués de Campo.

es considerablemente mayor al de los trazados anteriores y ello permitió la colocación a ambos lados de filas de árboles.

El aislamiento en que queda el Arrabal de Tierra al producirse el ensanche de la ciudad y la ausencia de nuevas construcciones contribuyen al paulatino decaimiento de esta zona de la ciudad, que en otros tiempos gozaría de gran explendor e importancia. 
Por su parte el antiguo Arrabal del Mar que consiguió de la Diputación Provincial de Alicante su segregación respecto a Denia en 1837 con el nombre de Pueblo de Diana, denominación que mantuvo hasta 1839 , año en que fue definitivamente incorporado a la ciudad, entraria también en una situación de aislamiento, después del auge económico alcanzado por el desarrollo comercial que propició el puerto a lo largo del siglo XIX. Esta situación de marginalidad vendría provocada por el traslado del puerto de su antigua ubicación a la que tiene hoy día.

El estancamiento urbanístico, consecuencia del declive económico a raiz de la plaga de la filoxera en 1913 va a acentuarse en los años de postguerra, en los que sólo se van a llevar a cabo los proyectos, planificados con anterioridad, de prolongar las calles La Mar y Carlos Sentí. La primera, creada hasta la mitad, en el último tercio del siglo xIx, al enlazar la nueva zona de crecimiento con la salida de la ciudad, tiene como objetivo unir la ciudad con el puerto. Las nuevas edificaciones marcan una gran diferencia con las realizadas en el siglo pasado. Cerrajería de hierro, dinteles de piedra, madera en las puertas, en fin, un aspecto clásico-señorial contrasta con la parte ampliada, caracterizada por moles de pisos, de materiales pobres y sin ninguna estética en su construcción.
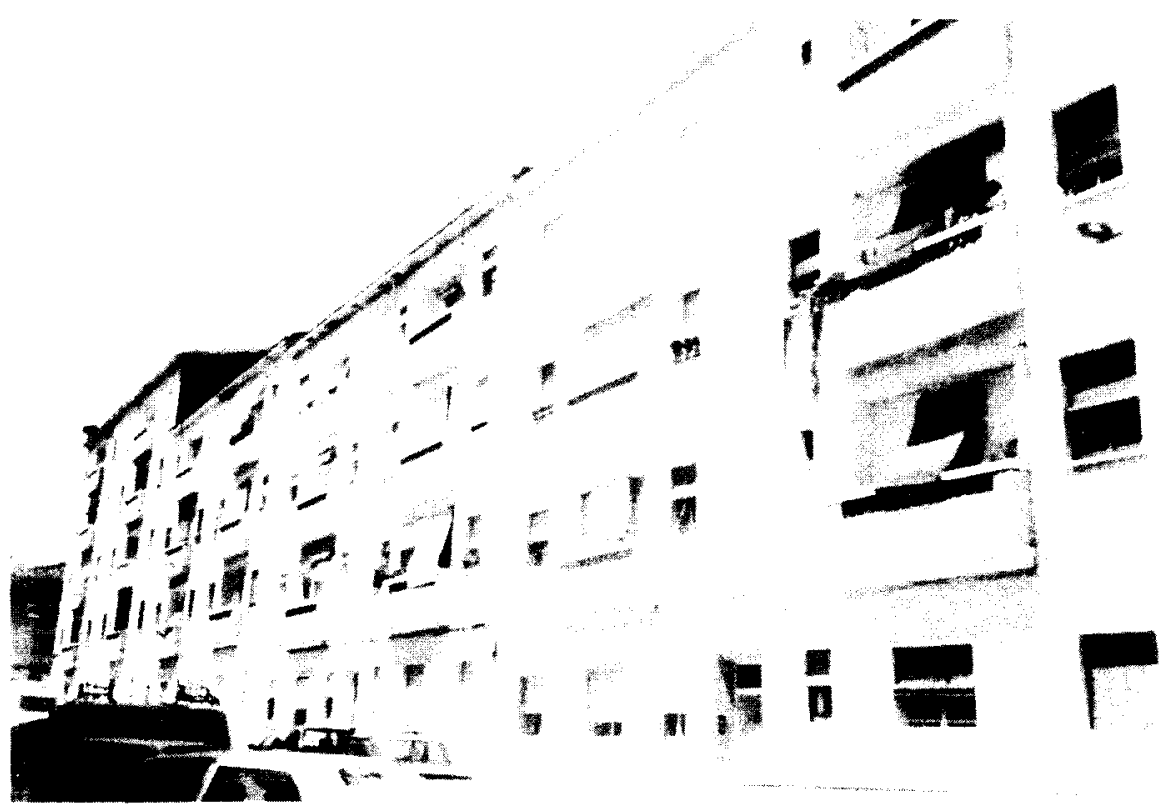

Ampliación de la calle La Mar en los años de la postguerra. 
La ampliación de la segunda calle, Carlos Sentí, se realiza debido al nuevo proyecto de construcción del mercado, trasladado desde la Glorieta. La construcción de éste obedece a los cánones franquistas de la época.

De las mismas características son las construcciones emprendidas por iniciativa estatal, ante la falta de viviendas. Son el grupo de viviendas “Ramón Cárdenas» y la plaza Pere Eiximen d'En Carros, unas edificaciones en manzanas, donde las casas o bloques de viviendas se organizan en torno a un gran patio central, fomentándose, de este modo la relación y convivencia entre los vecinos.

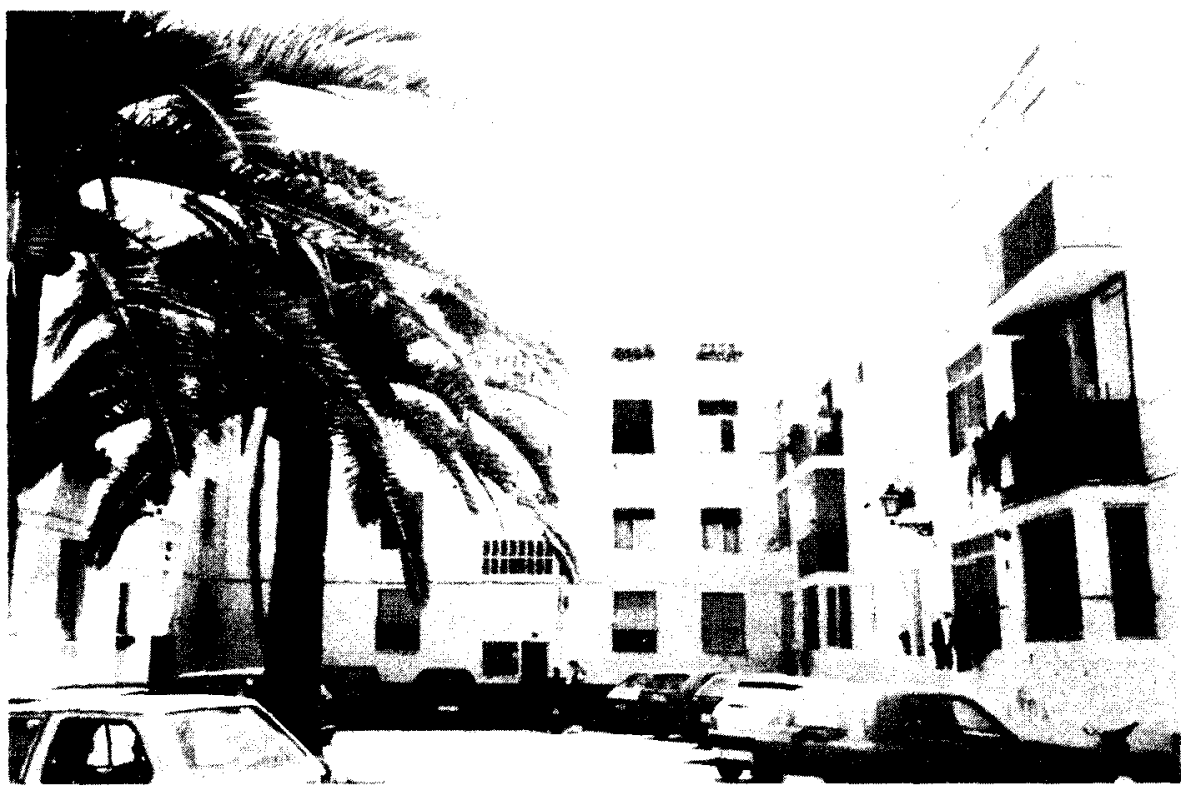

Grupo de viviendas "Ramón Cárdenas".

Por último, en el último tramo de la calle Marqués de Campo, no construida anteriormente y en sus alrededores, se va a planificar en algunas manzanas la creación de viviendas unifamiliares, rodeadas de un pequeño jardín —casas-jardín—, también en dicotomía con el resto de la zona.

\section{LA TRANSFORMACIÓN DEL ESPACIO URBANO DESDE LOS AÑOS 60}

Después de varios años de estancamiento económico y, consecuentemente demográfico (fig. 1), la década de los años 60 va a presenciar un 


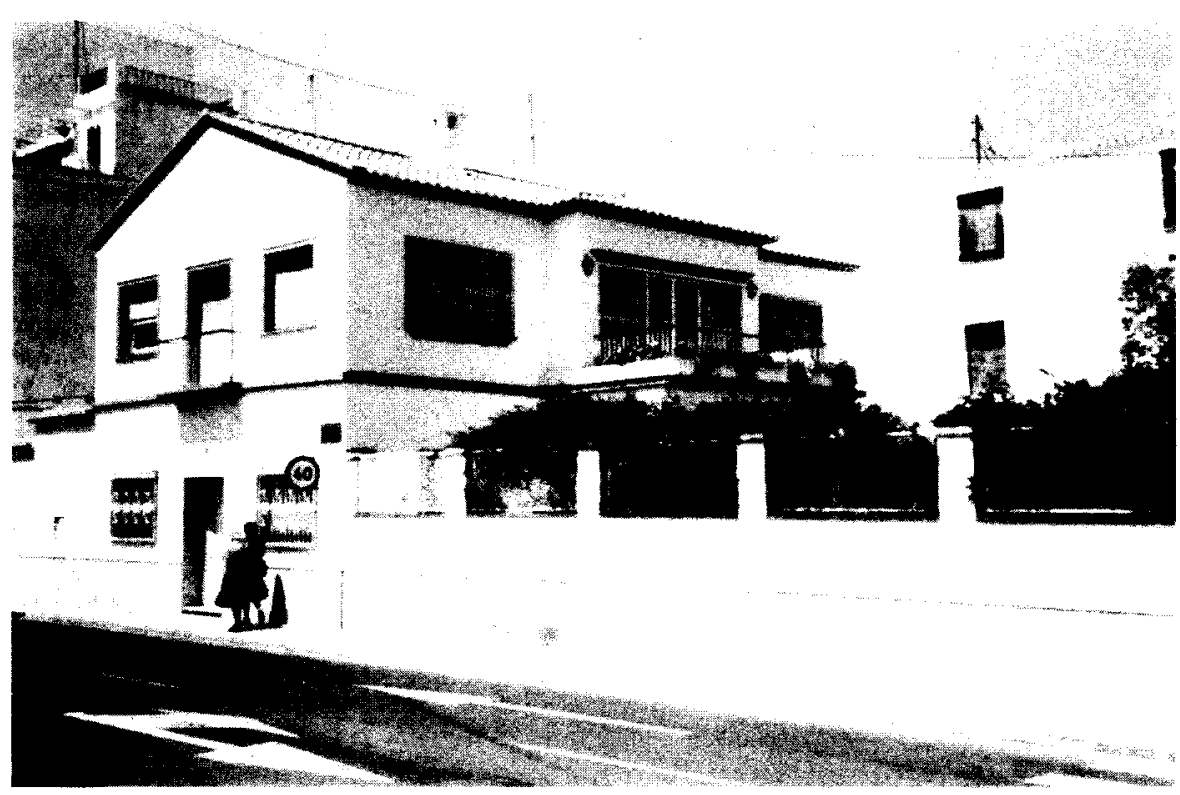

Casa ajardinada en las inmediaciones de la calle Marqués de Campo.

gran cambio en las estructuras económicas, demográficas, socio-profesionales y urbanísticas, produciéndose, de este modo, un viraje radical en el desarrollo y evolución de la ciudad y sus gentes.

La explosión turística en las costas del Mediterráneo y, concretamente en las de la Comunidad Valenciana, supuso una gran demanda de puestos de trabajo, lo que conllevó una acentuación del fenómeno inmigratorio, el cuál, como ya hemos comentado anteriormente, proporcionó, en un principio, mano de obra abundante y escasamente cualificada para el sector servicios y la construcción. A su vez, este fuerte contingente de población provocó la necesidad de crear nuevas zonas residenciales fuera del casco histórico de la ciudad.

Nos encontramos, pues, en los años 60, como la ciudad de Denia, incluyendo su zona periurbana, ha sido objeto de profundos cambios sociales y urbanísticos producidos por las transformaciones económicas que han tenido lugar y que han repercutido en su estructura interna.

Propietarios privados, promotores, inmobiliarias provocaron una transformación en el uso del suelo, donde a través de la especulación y del juego de la oferta y la demanda obtuvieron grandes beneficios acaparando los terrenos de más valor. 
Los poderes públicos no hicieron sino fomentar el boom urbanístico, permitiendo la libre edificación, para dar libre cauce a los principios capitalistas de obtención de máximos beneficios.

Uno de los espacios más afectados, consecuencia del boom turístico en los años 60 fue el litoral costero dianense, zona que se extiende desde el extremo N.O. al S.E., constituida por dos sectores, de características diferentes y separados ambos por el núcleo urbano. El primero, -zona N.O.- es el conocido con el nombre genérico de las Marinas, costa baja, de playa arenosa, está formada por varias playas, entre las que destacan las Marinas, Almadraba y Deveses.

El segundo, las Rotas, se extiende al S.E. y, a diferencia del anterior, es escarpado y rocoso, formando pequeñas calas, llegando en su interior al macizo del Montgó.

En diciembre de 1962 se redactó un "Plan General de Urbanización de las playas de Deveses, Almadraba y Marines", el cual, ateniéndose a la «Ley del Suelo y Ordenación Urbana» de 1956 — primera ley del suelo-, pretende «evitar la retención de terrenos por propietarios con el fin de especular sobre ellos" ${ }^{15}$.

Sin embargo, los efectos prácticos del Plan contribuirán a la consecución de los mayores beneficios, por parte de los agentes sociales responsables en la construcción de múltiples viviendas, destinadas a acoger y fomentar el turismo que, en esos años, comenzaba a desarrollarse.

"Considera solar edificable cualquiera que no esté en futuras vias públicas o espacios verdes, permitiendo todo tipo de construcciones: pareadas, en hilera o escalonadas a una distancia mínima de 30 metros y la pleamar, considerándose como libre la altura de los edificios» ${ }^{16}$.

De este modo se desarrolló la urbanización de $14 \mathrm{~km}$. de costa, desde el núcleo urbano al extremo N.O., transformando la base territorial existente -marjales, marismas, zonas montañosas...- (fig. 1) en diferentes modelos residenciales, mediante consecutivas reparcelaciones del terreno. La ampliación del eje que enlazaba con la carretera Nacional 332, paralela a la playa, ordenado en el Plan Urbanístico de 1972, que analizaremos posteriormente, articuló esta zona, lo que permitió un acceso más rápido a la ciudad y se impulsó la edificación. De este modo se zonificó dos partes, una al N. - próxima al mar-y otra al S. de la red viaria.

\footnotetext{
15. Plan General de Urbanización de las playas Deveses, Almadraba, Marınes. 1962. Archivo municipal de Denia.

16 Idem 8.
} 
Al mismo tiempo se llevó a cabo la adaptación del tipo de casa tradicional, existente en la zona, la «marina», que tenía la burguesía dianense como lugar de recreo y expansión.

En las Rotas, las consecuencias del boom turístico se manifestaron de forma distinta a la zona de las Marinas.

En esta zona, nos encontramos con un tipo de casa, la "rota", rodeada de pinares y caracterizada por tener una torre adosada. Aunque este tipo de construcción es ecléptico, la característica común de todas es su carácter señorial. Todas ellas se encuentran diseminadas a lo largo de la costa y constituian, también, la segunda residencia de la burguesía que se desarrollo a raiz del auge comercial de la pasa a finales del siglo XIX y cuya construcción se fomentó a raiz de la fundación por José Chabás de la "Sociedad del Clima de Denia" en 1908, cuyo objetivo era promocionar la ciudad, resaltando la benignidad del clima.

En los años 50 se va a producir un importante asentamiento de alemanes en el paraje de las Rotes, con la consecuente construcción de un importante número de chalets en esta zona.

Sin embargo, será en la década de los 60 cuando las construcciones residenciales proliferen, ocupando, no sólo el litoral costero, sino también la zona interior, llegando a los pies del macizo del Montgó, urbanizando importantes zonas de este, hoy, parque natural, cuyos limites imprecisos fueron presa de empresas constructoras.

La proliferación de construcciones se extendió llegando a otras partidas, creando diferentes complejos residenciales.

Todo este tipo de construcciones se realizaron de forma anárquica, aprovechando el beneplácito estatal, que con un supuesto Plan Urbanistico, como veremos más adelante, —el de 1966- permitió la libre construcción a las empresas promotoras.

El abancalamiento existente en el terreno obligó a que las construcciones del interior se adaptasen a la orografía escarpada, predominante en esta zona.

La posterior construcción de la carretera de las Rotas, que une Denia a Javea a través del interior impulsaría el desarrollo de edificaciones en esta zona.

El espacio interior del núcleo urbano también va a sentir los efectos urbanísticos del boom turístico de estos años.

La necesidad de ampliación de las zonas de uso residencial, motivada por el creciente aumento de la población, motivó que en 1966 se llevase a cabo el «Plan de Reforma Interior y Extensión de las Zonas N. y S. de la ciudad", con el objetivo de ordenar el territorio y dar respuesta a las necesidades creadas. Dicho Plan se completaría, este mismo año, con la aprobación de unas Normas Provisionales (hoja que se adjunta). 


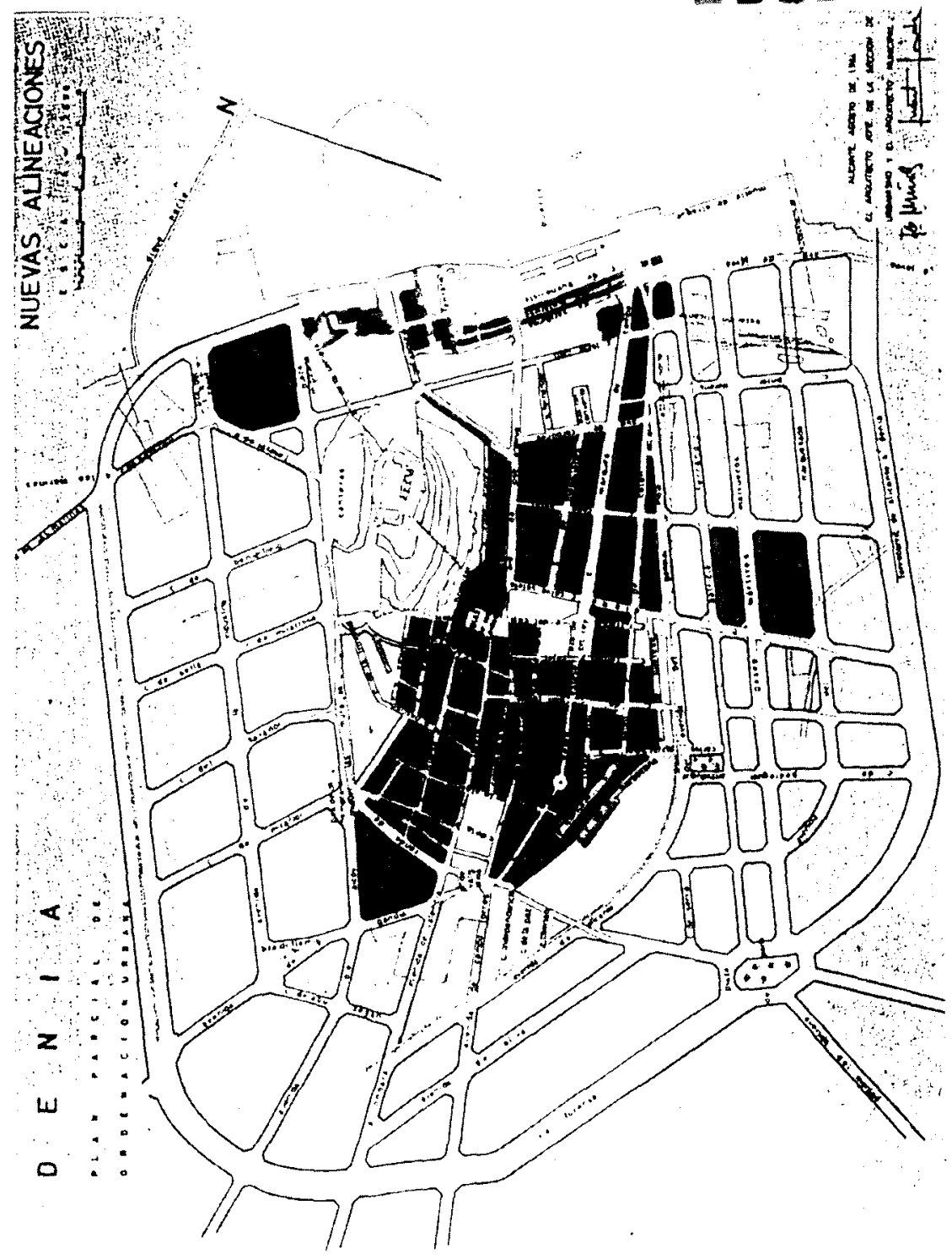


La zona que abarcaría la ampliación de la ciudad quedaba delimitada de la siguiente manera:

"Zona N.: Desde las estribaciones del castillo hasta la playa, y desde esta, hacia el O. llega hasta la línea de ferrocarril Carcagente-Denia. Por el E. hasta el puerto.

Zona S.: Desde el N. la carretera Cocentaina-Denia y el ferrocarril Carcagente-Denia, por el S. la Compañía de Estratégicos Secundarios de Alicante-Denia, al E. el puerto y al O. la Ronda $S$. que se proyecta que alcanza la ya proyectada plaza de París» ${ }^{17}$.

Se trata, pues, de la ampliación de la ciudad circunvalándola en forma de c (fig. 2), por la parte N., a partir de la Ronda de las Murallas, continuando al O. por la Avda. de Alicante - primera etapa del Plan-, que a través de la plaza Archiduque Carlos y Patricio Ferrándiz, comunicaba la ciudad con el puerto. Mientras la Avda. de Alicante tenia un carácter fundamentalmente residencial, en Patricio Ferrándiz y sus paralelas se mezclaba la función residencial con la ubicación de industrias ligeras. Por la parte N., de más reciente creación, el carácter de esta zona era claramente industrial.

Todo ello quedaría, a su vez, delimitado por una gran vía -la vía Focense- que circunvala a la totalidad de la zona ampliada y, consecuentemente, a toda la ciudad.

Con respecto al tipo de construcción, las Normas Provisionales, que ya hemos mencionado anteriormente, van a permitir la libre edificación, hecho que ya se habia venido realizando con anterioridad a la aprobación de dichas Normas. Basta con mirar el plano (fig. 2) para poder observar como las construcciones realizadas en estos años sobrepasan las alturas tradicionales existentes - bloques de 12 plantas frente al puerto-.

Predominaban los edificios de tres plantas en el centro del casco urbano, dos plantas en la periferia y una planta en la parte más antigua.

Las nuevas construcciones van haciendo desaparecer los espacios tradicionales, provocando, de este modo, una pobreza ambiental. Las Normas Provisionales no harían sino fomentar estas edificaciones, rompiendo la armonía urbanística.

17 Plan de Reforma Interior y Extensión de las Zonas N.y S. de la ciudad. Archivo municipal. 
Plan general de ordenación urbana de 1972

La actividad constructora iniciada en los años 60 , consecuencia del desarrollo turístico, no sólo no había descendido, al contrario, la bonanza habia aumentado considerablemente. Baste con señalar como en el año 1966 hubo 572 expedientes de obra, mientras que 1972, fueron $1248{ }^{18}$. Podemos intuir, sin muchas probabilidades a equivocarnos, el hecho de que la mayoría fueran aprobados.

La necesidad de racionalizar esta euforia constructora, no sólo en esta ciudad, sino en toda la costa, llevó a la creación, en 1971, de un Plan Comarcal de Ordenación Urbanística de la Costa Blanca (zona N.), con versiones concretas para cada una de las ciudades pertenecientes a esta área.

De esta forma, en 1972, se aprobó el Plan General de Ordenación Urbana del termino municipal de Denia, para un periodo previsto de 15 años. El objetivo fundamental de este Plan está recogido en su presentación: "Tratar de evitar la dispersión de servicios, acumulación excesiva de densidades en pequeñas áreas, congestión de tráfico, invasión de áreas que interesa proteger, destrucción de los valores paisajisticos, etc. y pretende ordenar el desarrollo urbanístico existente." ${ }^{19}$.

Los puntos más importantes de este Plan serían los siguientes:

1. Establece los siguientes usos del suelo:

Residencial y comercial

Servicios especiales

Industrial

Espacios verdes

Deportivo

Viario principal

\begin{tabular}{|c|c|}
\hline las. & $\%$ \\
\hline 193,4 & 52, \\
\hline 30,0 & 8 \\
\hline 54,0 & 14 \\
\hline 41,0 & 11 \\
\hline 24,0 & 6 \\
\hline 25,6 & 7 \\
\hline
\end{tabular}

2. El coeficiente de edificabilidad queda establecido en un máximo de $5,0 \mathrm{~m} / \mathrm{m}$. para el suelo urbano y de $0,6-0,3$ y $1,0 \mathrm{~m} / \mathrm{m}$. para el "suelo rústico de interés turístico" - denominación otorgada a la zona periurbana costera de la ciudad-.

Como podemos apreciar ha disminuido el grado de las edificaciones con respecto al periodo anterior (ver Normas Provisionales de 1966).

i Fuente: Archivo municipal.

19 Plan General de Ordenación Urbana. Denia. 1972. 
3. Con respecto a la altura máxima de los edificios, viene determinada, como podemos observar, dependiendo del ancho de la calle.

\section{Número de plantas}

Ancho calle

menor de $8 \mathrm{~m}$.

de 8 a $12 \mathrm{~m}$.

Grado 1

Grado 2

Grado 3

mayor de $12 \mathrm{~m}$.

4

5

6
3

4

5
2

3

4

También podemos comprobar como las alturas de la edificación han bajado significativamente, sobre todo en el casco histórico, para que «no se afecte a la escala y composición de los conjuntos", aunque no se ha tenido en consideración el estilo y tendencias arquitectónicas del pasado, de este modo, la construcción, ni los materiales son totalmente distintos, provocando, así, un deterioro en la calidad del espacio construido.

4. Con respecto a las zonas verdes, sensibilizándose de su inexistencia, prevee dos zonas, una cerca de la zona deportiva y la otra al S. del casco urbano.

La protección de la zona forestal no se demuestra pues, aunque, por un lado impide las urbanizaciones, por otro, permite que la destrucción del arbolado pueda llegar al $10 \%$ del total existente. Esto explicaría la ocupación y urbanización de las colinas al pie del Montgó, con los beneficios económicos que ello comportó.

5. Este Plan reserva $70 \mathrm{Has}$. para el planeamiento del área industrial, localizando dicha zona al $\mathrm{O}$. del casco urbano, en la carretera de Ondara, por la facilidad que presenta este espacio para las comunicaciones.

6. Propone la creación de una carretera a lo largo de la costa, a ambos lados del núcleo urbano.

Hacia el N.O. esta carretera, enlazaría con la Nacional 332, acortando el acceso a la ciudad y zonificando dos partes en las Marinas, una cerca del mar, donde se fomentará los usos residenciales y, la otra, al S., utilizada, en un principio, para la creación de infraestructuras destinadas a esta zona.

Por el S.E. el esquema lineal se alargaria hacia el cabo S. Antonio y estribaciones del Montgó, lo que facilitaria la urbanización de estas zonas.

7. Se mantiene la línea de ferrocarril - vía estrecha-, pero se desvía su trazado, evitando, así su entrada en el núcleo urbano.

8. Se planifica la creación y ensanchamiento de caminos vecinales.

9. El Plan prevee proteger los terrenos de huerta. 
10. El asfaltado de las más importantes calles, sólo el $30 \%$ lo estaban.

La década de los años 70 ha conocido un desarrollo urbanístico y demográfico de grandes proporciones, que deja entrever la todavía carencia de infraestructuras adecuadas.

El desarrollo urbanístico se ha centrado, en esta ocasión, sobre todo, en la zona costera, dimensionado por la escasez del equipamiento hotelero existente. Al mismo tiempo se produce el sucesivo deterioro de muchas viviendas del centro histórico por falta de subvenciones e inversiones estatales o privadas, interesadas en incrementar los valores de cambio del espacio urbano, y mientras los propietarios del suelo y los promotores de la construcción sólo buscan obtener el máximo beneficio, los poderes públicos no han sido capaces de mantener un bien colectivo, herencia de un pasado histórico.

El deterioro que habia alcanzado diferentes áreas y conjuntos urbanísticos llevó a la confección en 1981 del PLAN ESPECIAL DEL PATRIMONIO HISTORICO-ARTISTICO Y MODIFICACION PUNTUAL DEL PLAN GENERAL DE DENIA, en el que "se considera preceptiva la suspensión de licencias de derribo, reparcelación, reformas, sustituciones, reconstrucciones, o cualquier otra acción que implique modificación del estado, tanto interior como exterior, así como todos los elementos urbanos, comprendidos en las áreas que a continuación se especifican» ${ }^{20}$ :

1. Edificios con valor monumental o histórico artístico. Serían los declarados de este modo por la Dirección General de Bellas Artes:

a. En el núcleo urbano:

- Castillo y murallas

b. En el disperso:

- Ermita de S. Juan.

- Torre del Gerro.

2. Edificios con valor de conservación estricta. Son aquellos que contribuyen a la fisonomía de su entorno y a las características arquitectónicas, tanto internas, como externas.

a. En el núcleo urbano:

- Casa consistorial.

- Parroquia Ntra. Sra. Asunción.

20 Plan especial del patrimonio histórico-artístico y modificación puntual del Plan General de Denia, 1983 , pág. 24. 
- Convento de S. Francisco y Parroquia de S. Antonio.

- Convento de las Agustinas.

- Palacio de Dos Aguas. (Sanatorio-Maternidad antiguo).

- Convento e Iglesia. Jesús Pobre.

- Casa Abadía. La Jara.

- Iglesia de S. Mateo. La Jara.

b. En el disperso:

- Ermita de Santa Paula.

- Ermita de Santa Lucía.

- Casa de Torrecarrals.

- Alquería de Colomer.

- Torre de la Almadraba.

- Torre del Cherro.

- Escalera del Maestre Patricio.

- Cova Tallada.

- Cala de l'Aigua Dols.

- Cementerio de los ingleses.

- Conjunto de las Covas de l'Aigua y Borrumini y su lápida romana.

- Pou de la Mountaya.

- Pou del Pilars.

- Muralla del Fortí (restos),

3. Edificios con valor de tipología tradicional. Son aquellos que deben mantener su estilo arquitectónico y elementos característicos, internos y externos.

a. En el núcleo urbano:

- Hostal del Comercio y conjunto arquitectónico-urbanístico de la $\mathrm{C} /$ Marqués de Campo entre las calles Diana y Carlos Sentí (excepto casa $n^{\circ} 16$ ).

- Conjunto arquitectónico-urbanístico de la $\mathrm{C} /$ del Cop (excepto casa

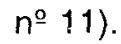

- Conjunto arquitectónico-urbanístico de la Plaza del País Valenciá (excepto no 7, 9 y 10).

- Conjunto arquitectónico-urbanístico de la manzana entre las calles Pare Pere, Horno de Algarra, Mayor y S. José.

- Conjunto arquitectónico de la calle La Mar hasta la calle Fora Mur. 
- Fábrica del Gel y su manzana.

- Resto del conjunto arquitectónico-urbanístico del Raval Baix-la-Mar entre las calles del Puerto, Plaza de S. José, Ronda de las Murallas, Jaime I, Gual Villalbi, Pza. de Benidorm y frente marítimo.

- Conjunto arquitectónico-urbanístico de la estación del N

- Conjunto arquitectónico-urbanístico del barrio del Les Roques.

- Conjunto arquitectónico urbanístico del caserío adosado a la muralla en las calles del Hospital y del Trinquet.

- Entorno y área de influencia del continuo de la Plaza de la Constitución y Consell.

- Entorno del colegio Maristas.

b. En el disperso:

- Conjunto El Biserot. Jesús Pobre.

- Casa Conaya. Jesús Pobre.

- Alqueria de Llano

- $\quad$ " Marqués de Cáceres.

- $\quad$ " Ferrando.

- " Benixaina

- Torreta Girona

- " El Palmer

- " Alter

- "Portolés

- " Buenavista

- " Gavilá

- " De Baix

- " Ferrando

- "La Moya

- " Pastor

— " 83

- " Restaurante Finita

- " Merle

- " 91. Los Patos

- " 93, " 


\section{- $\quad$ " 90, C Rotes de Oliver}

- Chalet n 420. Sector Teixidor

\section{- " La Marineta}

Lo que parecía que habia sido un cambio en la sensibilización de la administración, con la confección de este PLAN ESPECIAL y que conllevaría una conservación de los espacios heredados del pasado, pronto se vería como las presiones que se ejercieron para su modificación con el objetivo, nuevamente, de no estar sujetos a ordenanzas y poder modificar los elementos de los edificios o los propios edificios en sí, tendrían su efecto poco tiempo después, cuando quedaron modificadas varias de las disposiciones acordadas en dicho PLAN. Estas son las siguientes:

1. Exclusión del PLAN: la casa y jardín de D. Roque Chabás, el edificio de los H.H. Maristas, Almacén de los Ingleses, Estación de tren de Alicante, Lonja de pescado y la Fábrica de Gas.

2. Modificación de las alturas de los edificios de la calle Marqués de Campo, Plaza del País Valencià y calle La Mar, que aumentarian una altura más.

3. Los edificios del Hotel del Comercio, el $n^{\circ} \mathbf{5}$ de la calle Arzobispo Melo y la Fábrica de hielo pasarian de la categoría de conservación estricta a la de tradicional.

4. Cambia el planteamiento de obligado cumplimiento por el de recomendación en lo que se refiere a algunas normas dictadas en dicho PLAN.

Así pues la pretensión de hacer un Plan riguroso de conservación quedó en una mera ilusión; «la realidad no se rige por las leyes de la naturaleza, sino por la lógica del beneficio y del mercado, por influencias colectivas e intereses sociales contrapuestos, por el papel de los representantes políticos" ${ }^{21} \mathrm{y}$, en menor grado, por historiadores, urbanistas y personas, en general, con la suficiente sensibilidad para hacer que la ciudad no se convierta en un núcleo irracional, resultado de la priorización de los intereses económicos, sociales o políticos.

\section{Plan general de ordenación urbana de 1992}

La creciente complejidad de la ciudad obliga a una más detallada planjficación, en la que se pretenden resolver los cada vez mayores problemas

21 Zarate Martín, Antonio: “El espacio interior de la ciudad”. Editorial Síntesis, Madrid, pág. 71. 
que comporta, con el fin de crear una infraestructura adecuada a las necesidades que tiene y que pueden ir generándose, debiendo resolver los problemas concernientes a la creación de nuevas viviendas, estructura de los edificios, suministro de agua, energía eléctrica, alumbrado, la depuración y vertido de aguas residuales, la limpieza y recogida de basuras, evitando el vertido de vertederos incontrolados, creación de vías de comunicación, sin olvidar la protección del medio ambiente y del patrimonio histórico y cultural.

Las preocupaciones de este tipo han tenido, en muchos momentos, una traducción circunscrita a intereses concretos. La vivienda, el hábitat, han quedado, por lo general, abandonados a su movimiento espontáneo. Actualmente, en cambio, es la principal preocupación de la planificación urbana, y no sólo por la perspectiva de una ordenación social, sino por la amenaza que un desarrollo anárquico pueda provocar en la ciudad. Frente a la urbanización espontánea, característica de la Edad Media, y que se repite, de alguna forma, a raiz del boom turístico-demográfico de los años 60 , la urbanización dirigida exige una planificación, con el fin de asegurar unas mejores condiciones de vida y trabajo.

Para organizar, pues, el territorio y crear los elementos determinantes del desarrollo urbano se redactó en 1987 el presente Plan de Ordenación, siendo aprobado definitivamente en 1992. Este programa de actuación será revisado cada cuatro años.

En este Plan se ha establecido una clasificación del suelo en:

A) Suelo urbano.

B) Suelo urbanizable: son las áreas que en dos planes cuatrienales, es decir, en ocho años, serán convertidas en suelo urbano.

C) Suelo no urbanizable. Son el resto de las áreas que no se considera conveniente urbanizar.

La Ley del Suelo preve dos categorias de suelo urbanizable: programado y no programado. Esta última correspondería a la de suelo no urbanizable.

Las superficies que ocupan cada uno de los usos del suelo urbano son las siguientes

Edificable

Verde público

Deportivo

Equipamiento

Red viaria

Protección costa y barrancos

Fuente: Plan de Ordenación Urbana 1992.

$\begin{array}{cr}888,28 \text { Has. } & =68,1 \% \\ 100,77 " & =7,7 \% \\ 10,75 " & =1,1 \% \\ 24 & =1,7 \% \\ 245,60 " & =18,8 \% \\ 33,80 " & =2,6 \%\end{array}$


En el mapa que se adjunta están delimitadas las distintas partidas municipales, que coinciden con barrancos, caminos y carreteras, así como las áreas de suelo urbano, urbanizable programado y suelo no urbanizable, pudiendo apreciarse como la áreas de suelo urbano corresponden, además de los núcleos de Denia y polígono industrial, La Jara y Jesús Pobre -estos dos últimos pedanías de Denia - a la línea de costa que discurre de O. a E., penetrando, en esta última, hasta las estribaciones del Monte Montgó. Las áreas urbanizables corresponderían fundamentalmente al S. de la carretera de Las Marinas y los alrededores de los núcleos de La Jara y Jesús Pobre, quedando como áreas no urbanizables las que tienen un mayor interés agrícola - - y y S.O.- y ecológico - M. Montgó-.

La distribución de los diferentes tipos de suelo según las distintas áreas es la siguiente:

\begin{tabular}{lccc}
\hline & S. URBANO & $\begin{array}{c}\text { S. URBANIZABLE } \\
\text { PROGRAMADO }\end{array}$ & S. NO URBANIZ. \\
\hline DEVESES & 120,1 Has. & 74,85 Has. & \\
\hline ALMADRABA-MOLINS & 67,9 Has. & 110,45 Has. \\
\hline LAS MARINAS & 223,0 Has. & 212,94 Has. \\
\hline NÚCLEO Y EXT. & $\begin{array}{l}287,2 \text { Has. } \\
\text { LAS ROTAS }\end{array}$ & 90,75 Has. \\
\hline RACONS & 888,0 Has. & \\
\hline LA JARA & 80,8 Has. & 117,18 Has. \\
\hline JESÚS POBRE & 17,0 Has. & 55,79 Has. \\
\hline P.E.MONTGO & 19,2 Has. & 214,20 Has. \\
\hline RÚSTICO NORMAL & 530,0 Has. & \\
\hline TOTAL & 1833,20 Has. & 876,17 Has & $3.902,13$ Has \\
\hline
\end{tabular}

Fuente: Plan de Ordenacón Urbana de 1992.

Para gestionar la ordenación del suelo el Plan en objeto de estudio contiene unas Normas de planificación, cuyos puntos más importantes estarian recogidos en la hoja que se adjunta. Además, dicho Plan contempla los siguientes puntos:

- Creación de Planes Especiales de Reforma Interior: Torrequemada, Fora Mur, Chabás, Protección de S. Nicolás y Plan de la zona Las RotasMontgó. 
Población y desarrollo urbano de la ciudad de Denia

\begin{tabular}{|c|c|c|c|c|c|c|c|c|c|c|}
\hline 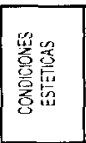 & 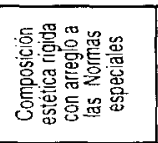 & 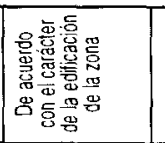 & 急 & 善 & 善 & 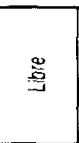 & 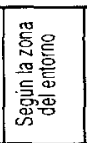 & 善 & 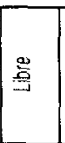 & \\
\hline 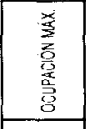 & 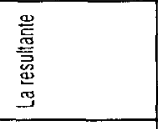 & 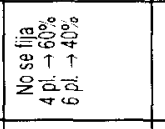 & 喽 & 离 & 今。 & 总 & 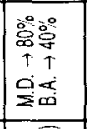 & 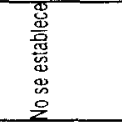 & 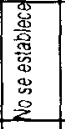 & 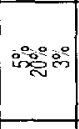 \\
\hline 兽 & 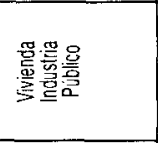 & 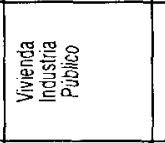 & 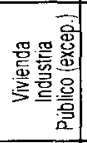 & 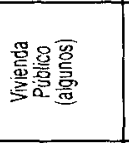 & 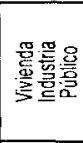 & 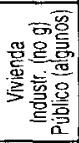 & 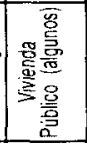 & 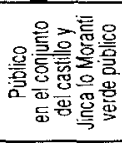 & 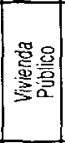 & 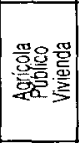 \\
\hline 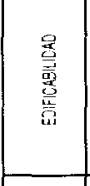 & 硠 & 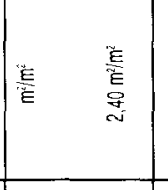 & 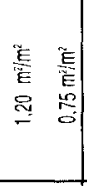 & 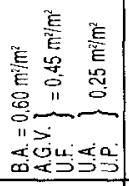 & 簏 & 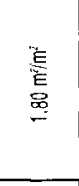 & 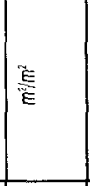 & & 铻 & 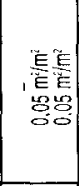 \\
\hline 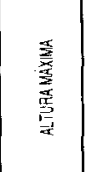 & 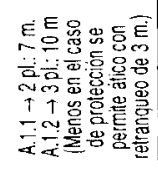 & & 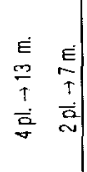 & 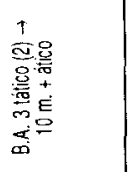 & 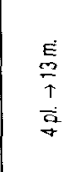 & 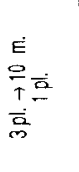 & 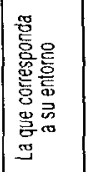 & 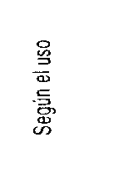 & 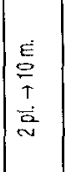 & 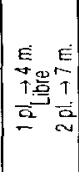 \\
\hline 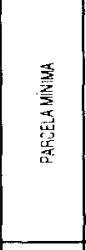 & 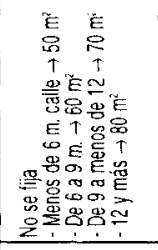 & 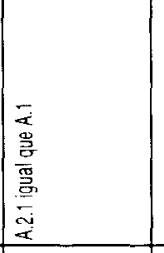 & 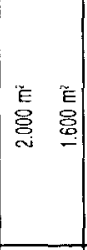 & 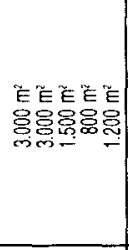 & 蒿 & $\begin{array}{l}\text { 苂 } \\
\stackrel{8}{8}\end{array}$ & 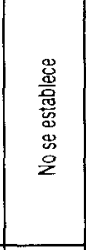 & 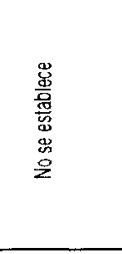 & 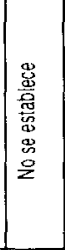 & 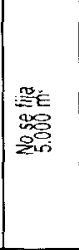 \\
\hline 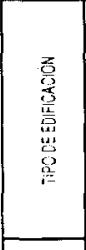 & 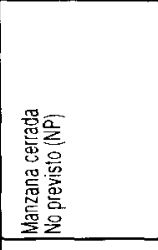 & 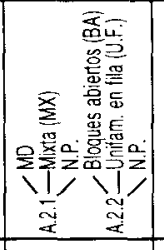 & 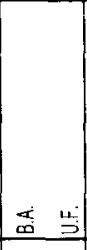 & 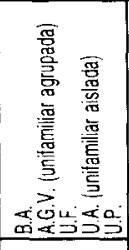 & 我是 & 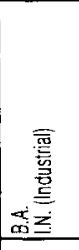 & 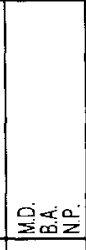 & 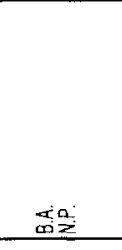 & $\frac{\pi}{\infty}$ & 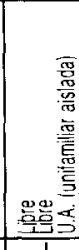 \\
\hline 萦 & 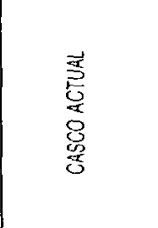 & 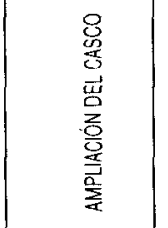 & 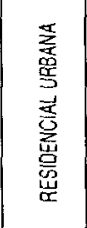 & 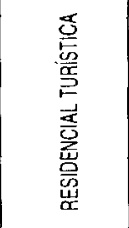 & 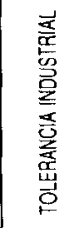 & 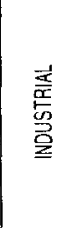 & 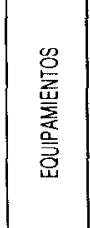 & 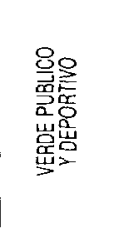 & 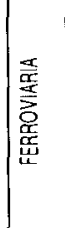 & 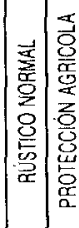 \\
\hline 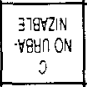 & & & & & & & & & & गัญ \\
\hline 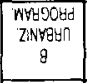 & & & $\infty$ & 品 & $\stackrel{\text { 吊 }}{ }$ & $\stackrel{\mathscr{m}}{\dot{m}}$ & 蒠 & $\underset{m}{\infty}$ & & \\
\hline 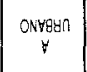 & $\alpha$ & $\dddot{x}$ & $\ddot{x}$ & $\dot{8}$ & $\ddot{x}$ & 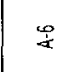 & ; & $\stackrel{\infty}{x}$ & 采 & \\
\hline
\end{tabular}


El jardín de la casa del Historiador Chabás quedará incorporado a la zona verde prevista, respetando, en un principio, la casa, pero dejando claro que podría ser utilizada.

- La densidad máxima permitida en suelo urbanizable será de 50 viviendas por Ha.

- No se podrán incorporar las carreteras públicas a las urbanizaciones privadas, debiéndose crear unas vías de penetración secundarias independientes.

- Obligatoriedad de crear plazas de aparcamiento: 1 plaza/100 m construidos, reservando el $2 \%$ de los aparcamientos a minusvalidos.

- bligación de mantener los edificios en condiciones de salubridad y ornato.

- Los espacios destinados a edificación estarán sujetos a unas condiciones concretas de aprovechamiento del suelo, que variarán según las áreas donde se realicen estas construcciones y cuyos conceptos y aprovechamientos se señalan en el cuadro que se adjunta a continuación.

La creación de una infraestructura adecuada, con un sistema constituido por espacios verdes y deportivos, por edificios de uso público: centros culturales, docentes, sanitarios, religiosos, ... y también otro de servicios: depósitos de agua, depuradoras, plantas de tratamiento de residuos sólidos, de energía eléctrica, ... es otro de los objetivos creados en este Plan.

- Se garantiza el abastecimiento de agua, siendo no inferior de 2501. habit./día. Para usos industriales será de $20 \mathrm{~m}$ dia/Ha.

- Habrá una red subterránea para aguas negras. En zonas residenciales que no estén en suelo urbano se autoriza la creación de sistemas individuales de depuración y vertido.

Existen también unas Normas de protección que, en el caso de la red de transportes, obliga a que las construcciones proyectadas fuera del suelo urbano deberán tener las siguientes distancias:

- Autopistas o autovias .....50 m.

- Carreteras nacionales ... . $25 \mathrm{~m}$.

- Otras carreteras ........ $18 \mathrm{~m}$.

- Ferrocarril. .......... $15 \mathrm{~m}$.

Para la protección de costas, se establece que, en suelo no urbanizable, la servidumbre de protección tenga una anchura de $100 \mathrm{~m}$. desde el límite del mar, y la servidumbre de tránsito sea de $6 \mathrm{~m}$. desde el límite del mar. 
Para proteger el medio ambiente se han adoptado una serie de medidas:

- Proteger las aguas para su abastecimiento y evitar su contaminación de los vertidos industriales

- Evitar la contaminación de las aguas marinas.

- Creación de depuradoras.

- Prohibición de que las industrias peligrosas se ubiquen a menos de $2000 \mathrm{~m}$

- Prohibir los vehículos que echen humos que dificulten la visibilidad. También se vigilará el nivel sonoro de los vehículos de motor.

- Prohibición de instalar motores fijos.

- En lo referente a las repoblaciones forestales, el Plan urbanístico señala que se valorarán no sólo las especies de fácil crecimiento, sino también el desarrollo de las autóctonas.

- Protección del patrimonio histórico-artístico y cultural. Se han considerado cinco áreas de protección: el yacimiento arqueológico de la ciudad romana, el castillo de Denia, el área de la Medina islámica, el área de "El Fortí» y el área de Alfarerias y el cementerio de época islámica.

Salvo la prohibición de edificar en terrenos donde existan yacimientos arqueológicos y la necesidad de solicitar un informe al Ayuntamiento si se desea "desarrollar el terreno", conjuntamente con las alturas previstas de las edificaciones - anteriormente mencionadas--, no existen otras normas para la protección de los espacios culturales de la ciudad, lo cual dista bastante de las normas aprobadas en el Plan Especial de Protección de 1982.

No cabe duda que las previsiones para llevar a cabo una buena ordenación del territorio están recogidas en este Plan, el problema radica en que se lleve a cabo la aplicación de las normas, lo cual, en muchos casos dista mucho de la realidad. Son de nuevo los intereses particulares y políticos los que priorizan sobre los intereses de la comunidad.

\section{TRANSFORMACIONES EN EL PAISAJE URBANO}

\section{Morfología de la ciudad}

La ciudad, como hemos podido apreciar en los capítulos precedentes, es el resultado de las continuas transformaciones socioeconómicas que se han ido produciendo a lo largo del tiempo. Así, la ciudad preindustrial, es un espacio pequeño, delimitado por una muralla defensiva en su momento de 


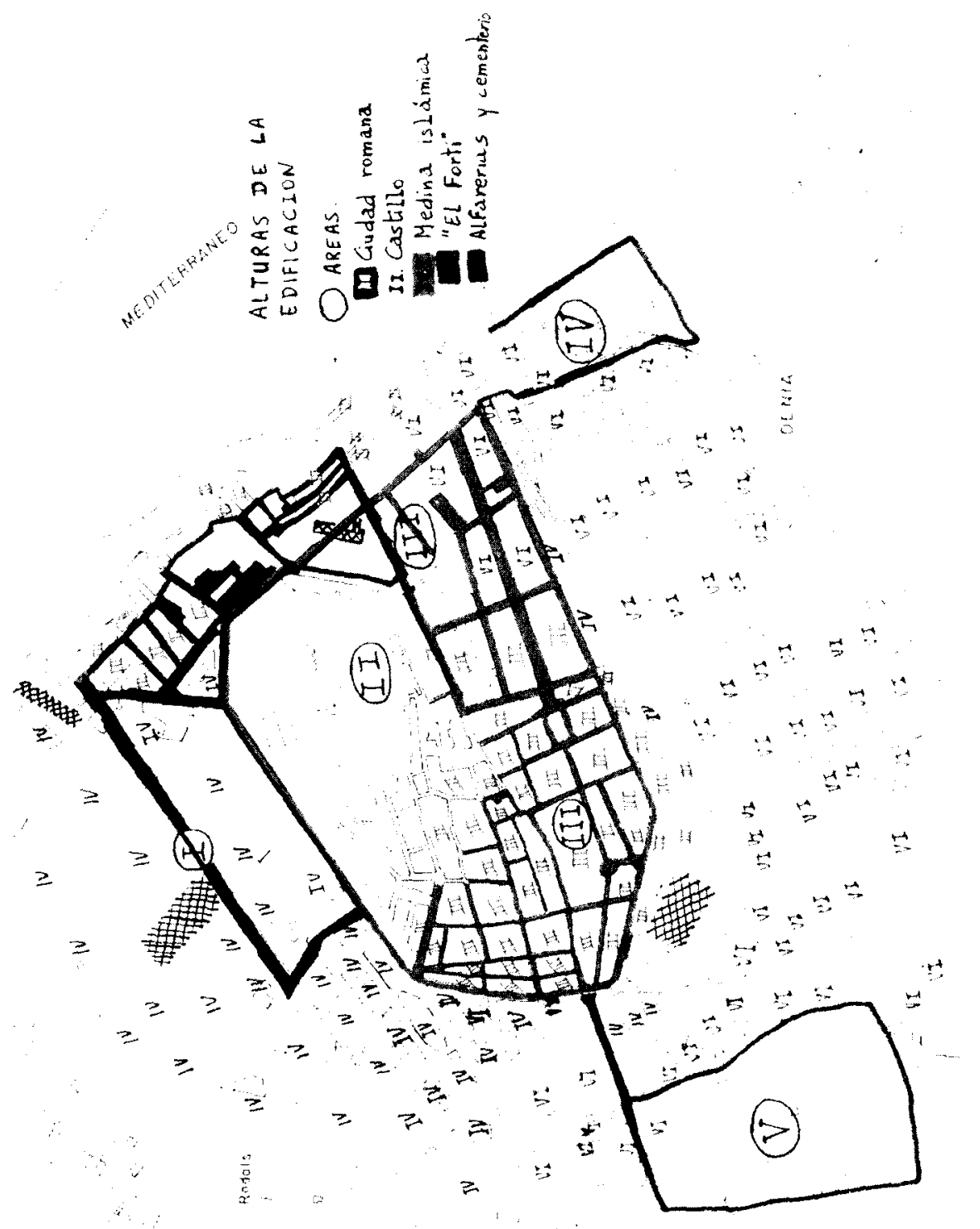


construcción, y en el que sobresalen las construcciones históricas propias: iglesias y grandes casas, con callejuelas estrechas y, a veces, tortuosas, en la que las clases altas ocupaban las zonas más céntricas.

La revolución económica que supuso para Denia el desarrollo de la pasa, provocaría la aparición de modelos urbanos dispersos. Este hecho, unido al boom turístico que se produce en los años 60 , fomentaría la dispersión urbana, separando, en muchos casos, la zona de actividad profesional de la residencial y generalizando el automóvil como medio de transporte.

Si la morfología nos proporciona la imagen visual de la ciudad, ésta nos muestra la huella de un pasado histórico, así como la influencia decisiva de su entorno geográfico que la ha influenciado de forma decisiva. El resultado es la conjunción de varios planos, consecuencia tanto de su ubicación histórica, como de la creciente expansión que la ciudad ha ido sufriendo con la aparición de nuevas áreas.

El cerro del castillo divide la ciudad en dos áreas, claramente diferenciadas: al N., los vestigios de la ciudad romana, y al S. la ciudad antigua y los ensanches de la misma.

El centro es un espacio reducido, para ocupar lo más posible el suelo. Presidido por el castillo, con una muralla defensiva, cuyos restos persisten todavía, su plano es irregular, con calles estrechas, de trazado más bien irregular y sus casas de una ó dos plantas. Viviendas, talleres y tiendas se mezclaban entre sí. La densidad era alta y las clases sociales más elevadas ocupaban los lugares más céntricos.

Con el crecimiento de la ciudad, se produce una mutación del centro urbano al centro funcional, en donde confluyen -Plaza de País Valencianouna serie de calles, que cortan a otras. La más importante de todas ellas y que constituye el centro neurálgico de la ciudad es la calle Marqués de Campo, que sirve además de enlace de la ciudad con la zona portuaria, y fue consecuencia de la planificación llevada a cabo en el siglo xIX.

El Plan de Reforma y Extensión de la ciudad promovido en los años 60 originaria la creación de un cinturón, alrededor del casco antiguo, cuyo trazado seguiría las directrices planteadas en el siglo anterior, conformando un plano ortogonal, de calles largas y rectas, cortadas por otras en ángulo recto.

El tipo y volumen de los edificios, resultante de la superficie y altura edificada, forman también parte del paisaje de la ciudad. Dependiendo de diferentes intereses, modos de vida, características socieconómicas y la concepción del poder en un momento determinado, nos encontraremos unas características en la construcción u otras. De este modo su significado es cambiante, dependiendo de unas circunstancias u otras. 


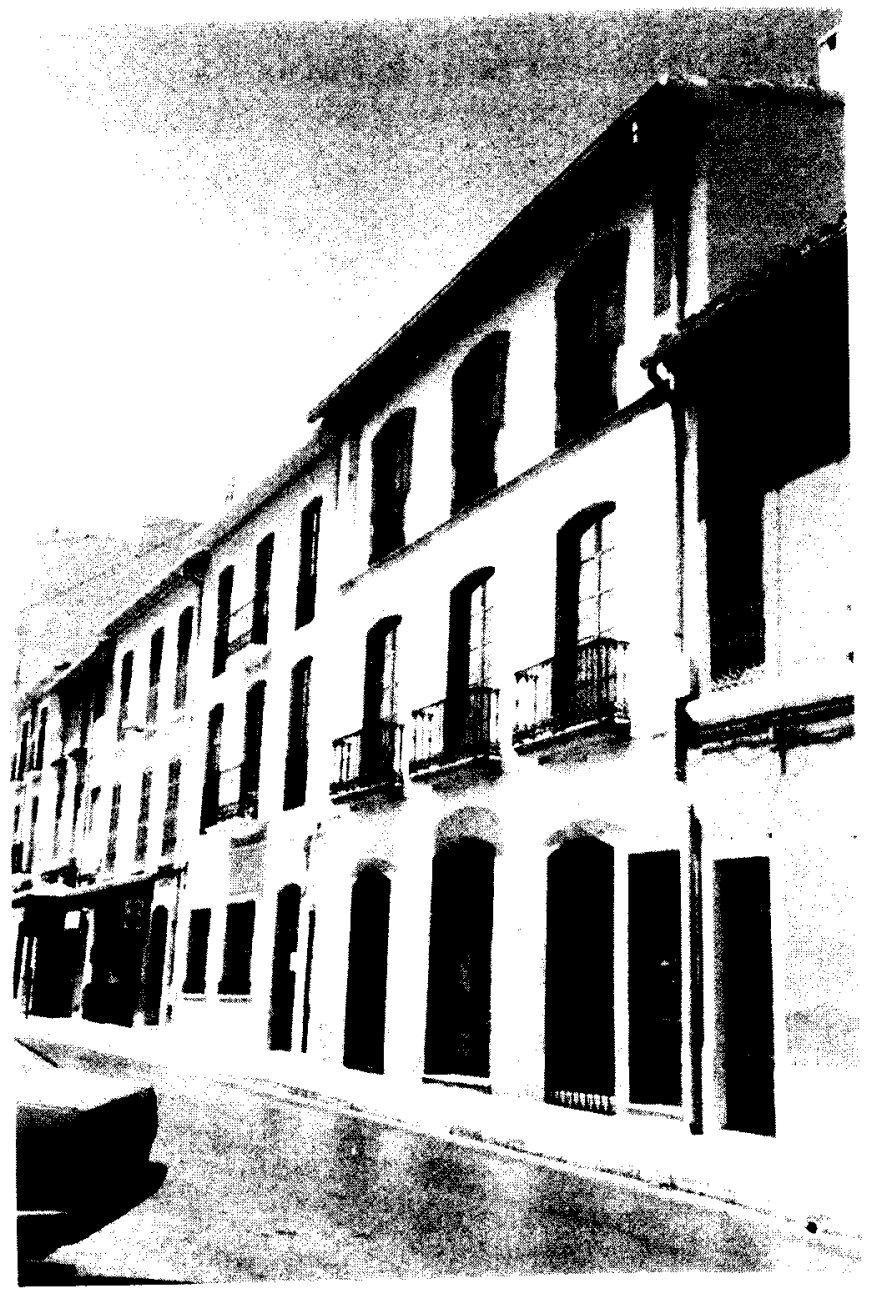

Calle La Mar

Uno de los rasgos que caracterizan a la vivienda es su carácter compacto, la ausencia de espacios abiertos o jardines. Las casas se agrupan en conjuntos continuos.

La vivienda predominante es la unifamiliar adosada, de una o dos plantas en la parte antigua. A veces, en este último tipo, cada una de las plantas pertenece a una familia distinta.

La casa de tres alturas corresponde a la expansión de finales del siglo pasado, localizada en la parte mas importante de la ciudad, la planta baja 
se dedica a actividades comerciales y las otras a viviendas, residiendo también una y, más frecuentemente, dos familias.

Las torres, consecuencia del boom urbano en los años 60 , están ubicadas en la Explanada - frente al puerto-, al final de la calle Marqués de Campo, Plaza del País Valenciano y calle Cop, principalmente, provocando una agresión y ruptura de la uniformidad residencial de las respectivas zonas.

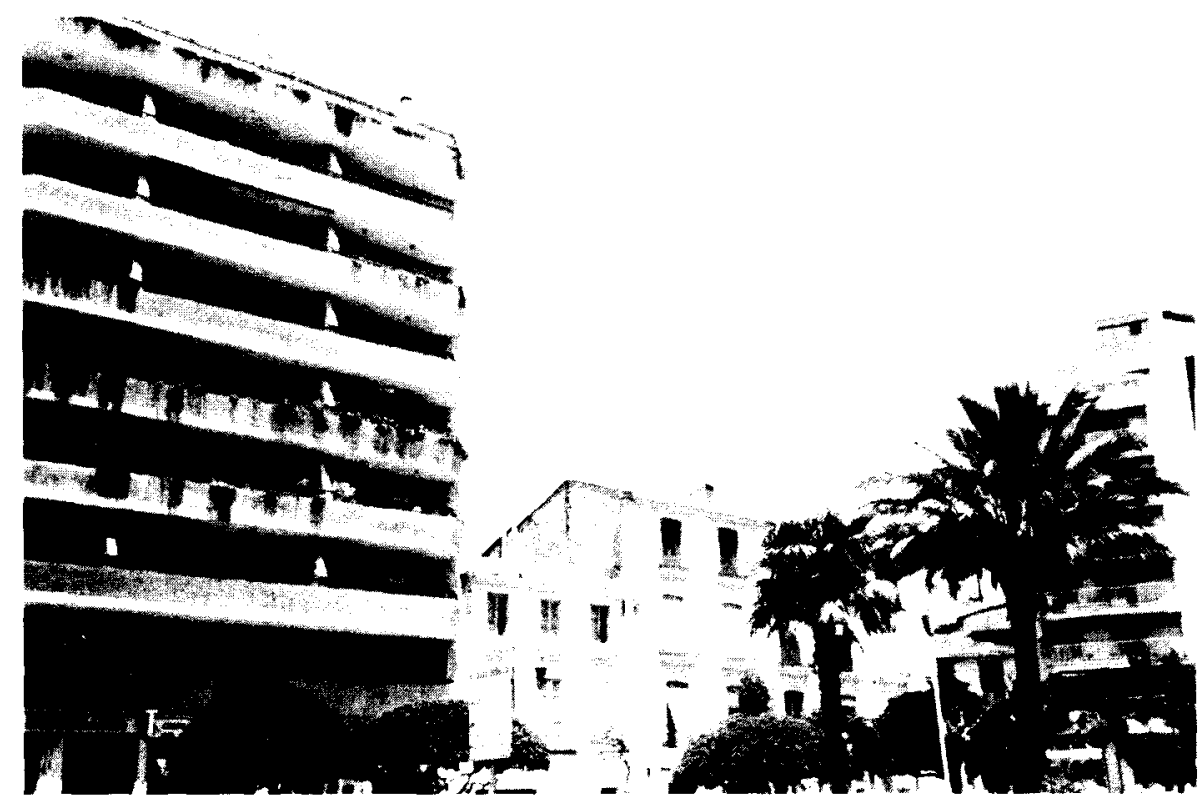

El ensanche de la ciudad está caracterizado por la construcción de bloques, de baja calidad, tanto de materiales, como en su diseño. Este gran conjunto está formado por grupos de edificios, destinados a uso residencial, salvo en las plantas bajas, homogéneos y sin interrupción.

La concepción de la ciudad vertical surge y se desarrolla por ser más barata que la ciudad tradicional, y en ella se alcanzan grandes densidades gracias a un desarrollo en altura.

Según el Plan Urbanístico de 1992, la composición familiar es de 3,8 habit./vivienda, siendo la extensión media de dichas viviendas, según el mencionado Plan de $137 \mathrm{~m}$, lo cual nos hace discrepar, porque pensamos que no corresponde con la realidad, ya que muchas de las casas tradicionales han sido divididas interiormente y su estructura cambiada, correspondiendo dos viviendas a una casa. Este hecho se produce debido a la carestía de las viviendas y, al consecuente, máximo aprovechamiento del suelo. 


\section{Usos del suelo}

Teniendo en cuenta las diferentes utilizaciones del espacio, en función de las actividades de la población y las características del medio físico, nos encontraremos con unos usos del suelo que han ido cambiando conforme ha ido evolucionando la ciudad y cambiando las actividades económicas en ella. Asi podemos clasificar el suelo en:

A) Rústico. Supone el $59,1 \%$ de la superficie total del municipio, con un total de 3902,13 Has. ${ }^{22}$. Dentro de esta clase podemos encontrar tres tipos:

- Forestal: pertenece el Montgó y sus laderas, lomas próximas a la pedanía de Jesús Pobre, Gargantas de Gata -estribaciones de la sierra de Soldetes-y al O., Racons de Calpero y Majada de Alcina.

El Montgó tiene $753 \mathrm{~m}$. de altitud y sus vertientes N. y O. pertenecen a Denia. En los años 20, la Junta Central de Colonización estableció en el Montgó lotes de monte, que fueron abalancados para ponerlos en cultivo. Actualmente estas tierras están abandonadas y son en ellas donde se están desarrollando las urbanizaciones.

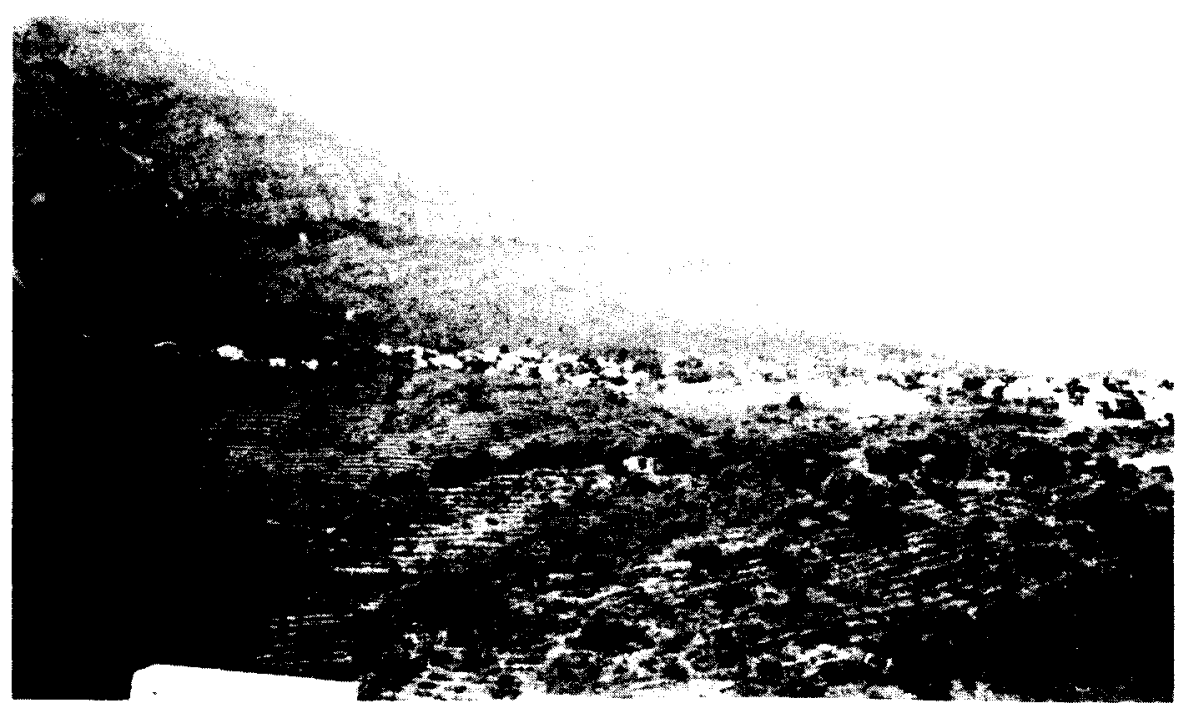

Laderas del Montgo.

27 Plan Urbanístico de 1992. 
La cubierta vegetal ha sufrido una intensa y continuada degradación, debido fundamentalmente a los incendios que la han asolado y al continuado proceso urbanistico desarrollado en esta zona. Las escasas repoblaciones se han realizado a base de pino carrasco (halepensis), efectuándose sobre 125 Has., de las 428 Has. que supone la propiedad del Estado. Sin embargo las repoblaciones privadas son inexistentes, y el fin último de estas tierras es la especulación y urbanización de las mismas.

Actualmente la Consejeria del Medio Ambiente ha puesto en marcha el Plan de Reforestación en un periodo de desarrollo de cinco años (19941999), tratando de evitar una mayor erosión del suelo y prevenir el riesgo de inundaciones, frecuentes en las zonas mediterráneas.

- Secano. Los cultivos de secano se desarrollan al S.: alquerias de Ferrando, Jesús Pobre, Gassent y Colomer, La Venta y Benisaim.

- Regadío. Es el cultivo preponderante, ubicado en el Plá de Denia, a excepción de las zonas de marjal, en la costa, ocupadas por el desarrollo de las urbanizaciones.

B) Urbanizado. Actualmente, la ciudad de Denia es un espacio diferenciado en grandes áreas de paisaje, que se han ido conformando a lo largo de su historia, para adaptarse a la nueva realidad que se demandaba, debido a circunstancias económicas y sociales concretas y que ha conllevado una nueva fisonomía de la ciudad: el centro, áreas comerciales, áreas residenciales, áreas industriales, zonas verdes y franja periurbana, todo ello interrumpido por la existencia de vias de circulación.

El centro. Es realmente complejo, pues las nuevas necesidades imperantes en la ciudad, han provocado un retraso en el aspecto "formal» de la misma, acarreando la decadencia y marginalidad de los barrios históricos, con el consiguiente deterioro de un gran número de viviendas por falta de subvenciones y por el desinterés, tanto de organismos públicos como privados. Son restos de antiguas formas de producción y se encuentra sometido, unas zonas, a una recuperación puntual, mientras, en otras se produce un deterioro progresivo, ya que sólo las iniciativas de algunos particulares han hecho que se rehabiliten y restauren algunas casas antiguas, aunque estos espacios ya no tienen las actividades que tuvieron en otro tiempo.

Sin embargo las posibilidades de rehabilitar todo el casco antiguo están cada vez más lejanas, porque la mayoría de las parcelas son muy pequeñas, están muy degradadas, con muchos inmuebles abandonados, grandes dificultades para la circulación, convirtiéndose, pues, en espacios marginales. 


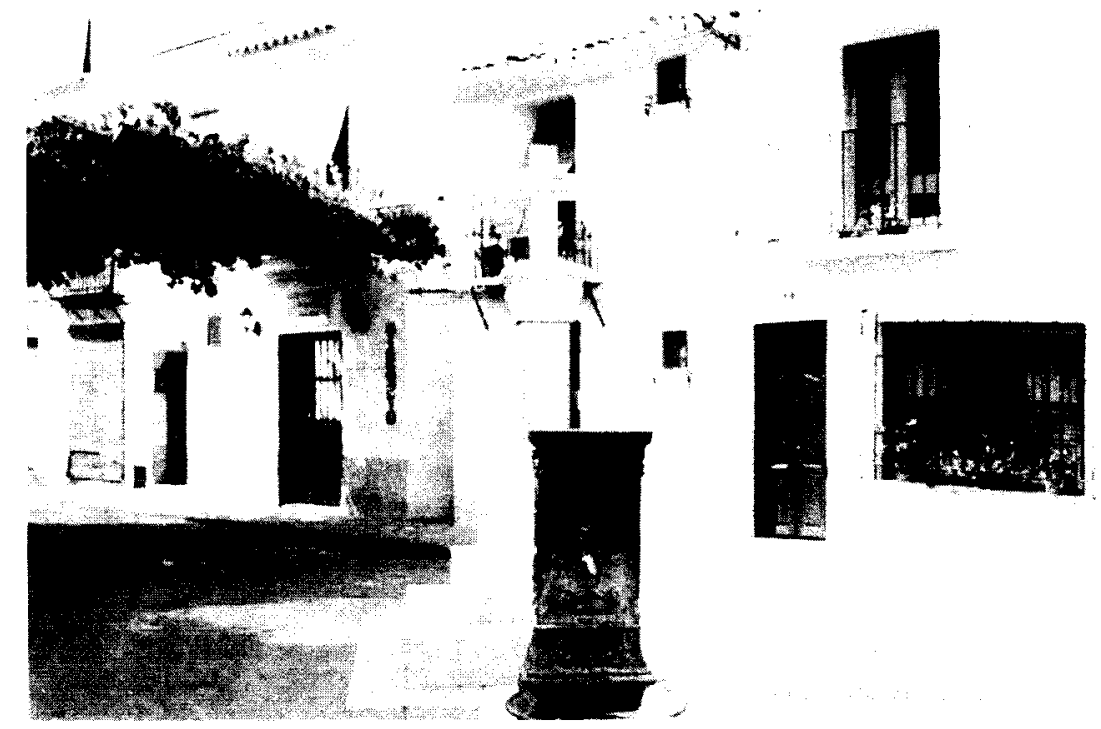

"BARRIO MARINERO», antiguo Arrabal del Mar.

La zona que constituye el verdadero centro de la ciudad es la calle Marqués de Campo. Conforma un verdadero espacio integrado, pues es la parte más dinámica de la ciudad. Es una zona cargada de signos y símbolos que van más allá de su carácter funcional, ya que constituye el lugar de encuentro, ya que la facilidad de acceso a él propicia las funciones de ocio y diversión. Constituye un verdadero nodo de la ciudad, ya que es el punto estratégico más importante de la misma, y en la que existen hitos en la misma que todos utilizan como puntos de referencia.

Es, al mismo tiempo, el área donde se desarrollan las actividades pertenecientes al terciario superior o cuaternario, sobre todo actividades de dirección y gestión. Constituye el C.B.D., centro de actividades, donde se llevan a cabo todas las funciones centrales de la ciudad. Es un centro claramente direccional, con un gran flujo de tráfico, tanto de vehículos, como de peatones.

La zona de transición o pericentro es el área que rodea a la calle Marqués de Campo -calle La Mar, Diana, Cop,...-, beneficiándose de la expansión de las actividades terciarias del centro. Ambas zonas constituían la zona residencial de la burguesía del siglo pasado, quedando, esta ultima, todavía como área residencial también. 
Áreas residenciales. Teniendo en cuenta que las diferentes áreas residenciales son el resultado de diferentes factores de índole socioeconómica y cultural, ya que la diferenciación social de las áreas residenciales resulta del precio de la vivienda y del nivel de rentas, podemos establecer tres grandes zonas:

1. Áreas residenciales del centro histórico. Constituyen el núcleo primitivo de la ciudad y su delimitación estaba ligada al hecho de que los desplazamientos de hicieran a pie. Dentro de este espacio podemos distinguir dos zonas, la más antigua, que como hemos comentado anteriormente, está en decadencia, donde se entremezclan viviendas de clases sociales medias-altas, bien rehabilitadas o mantenidas por las propias características de la calidad de los edificios, con viviendas más pobres y degradadas, ocupadas por clases sociales más bajas. La composición por edad suele ser la de una población envejecida. Una segunda área la constituiría la calle Marqués de Campo y sus alrededores, cuyas viviendas, herencia de la burguesía de finales del siglo XIX mantienen las características originarias y son ocupadas por personas con un estatus socioeconómico alto.

Sin embargo, la morfologia de ambas zonas se ve interrumpida por la construcción de bloques de pisos, que favorecieron el acceso de una clase media a ubicarse en este área residencial.

2. Áreas residenciales suburbanas. Constituyen la zona residencial más extensa. Son fruto del rápido crecimiento de la ciudad a raíz del boom de los años 60 , que conllevó un aumento en la demanda del suelo urbano y fue también unido a la generalización del uso del automóvil y actualmente, estas áreas forman parte de la ciudad, compuestas por bloques de pisos, de baja calidad generalmente y su composición social abarca desde niveles de renta medios a bajos, conforme nos alejamos del centro y están constituidos por familias jóvenes. Correspondería a la zona del ensanche que se produjo desde la Avenida de Alicante, plaza del Archiduque Carlos y Patricio Ferrándiz.

3. Áreas residenciales periurbanas. La competencia de distintos usos del suelo por ocupar el espacio limitado de la ciudad y, más concretamente el centro urbano, y el comportamiento de las familias de tener su residencia adecuada a sus necesidades y en función de su capacidad económica ha generado el desarrollo de las áreas residenciales periurbanas. Todas ellas invitan a la movilidad, pues estas áreas son más dinámicas que cualquier otro uso del suelo. Se hallan sometidas a continuos cambios que afectan a su morfologia, a la propiedad de las viviendas y a la composición ocupacional de las personas que viven en ellas. 

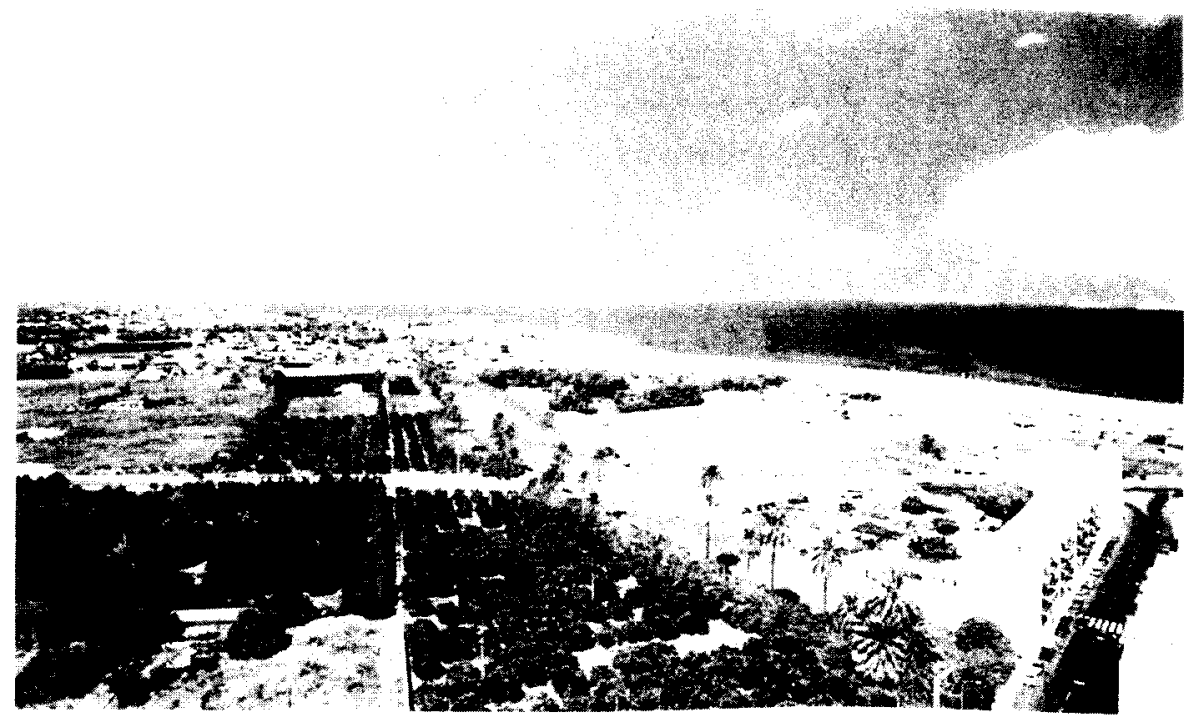

LAS MARINAS.

Una de las áreas residenciales periurbanas se encuentra en la línea de costa, a lo largo de la carretera de las Marinas y, enlazando, en dirección S.E., llegando hasta las estribaciones del Montgó. Ambas son fruto del boom turístico que se produjo en la década de los años 60 , aunque, como ya hemos comentado anteriormente, estas zonas constituían la segunda residencia de la burguesía dianense desde finales del siglo pasado.

Muchas de las viviendas continúan siendo segunda residencia, sin embargo el desarrollo de las urbanizaciones ha generado que muchas familias vivan durante todo el año en ellas, constituyendo su único hogar.

Las características de las viviendas son distintas de la zona de las Marinas a la de las Rotas. Mientras en la primera alternan viviendas unifamiliares, con pequeños bloques de pisos y casas adosadas o bungalows, en la segunda predominan las edificaciones individuales, de viviendas unifamiliares, cuyo tamaño y tipología varía desde las tradicionales, correspondientes al pasado, con grandes parcelas de terreno, con un estilo ecléptico, a las más modernas, cuya construcción corre a cargo de promotoras e inmobiliarias, cuya tipología es semejante en todas ellas y las parcelas son más pequeñas.

Otra de las áreas residenciales periurbanas es la que se extiende al $O$. y S.O. de la ciudad, donde se encuentran las grandes áreas cultivables. 


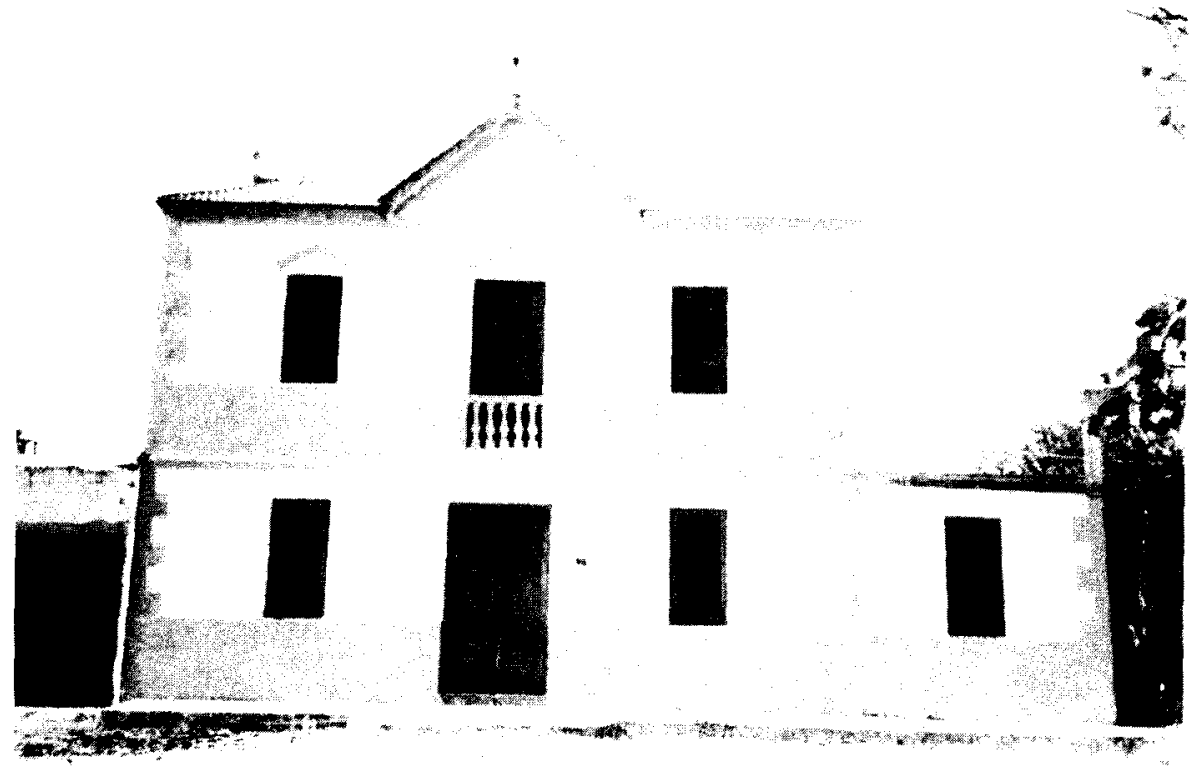

VIVIENDA UNIFAMILIAR ANTIGUA. LAS MARINAS.

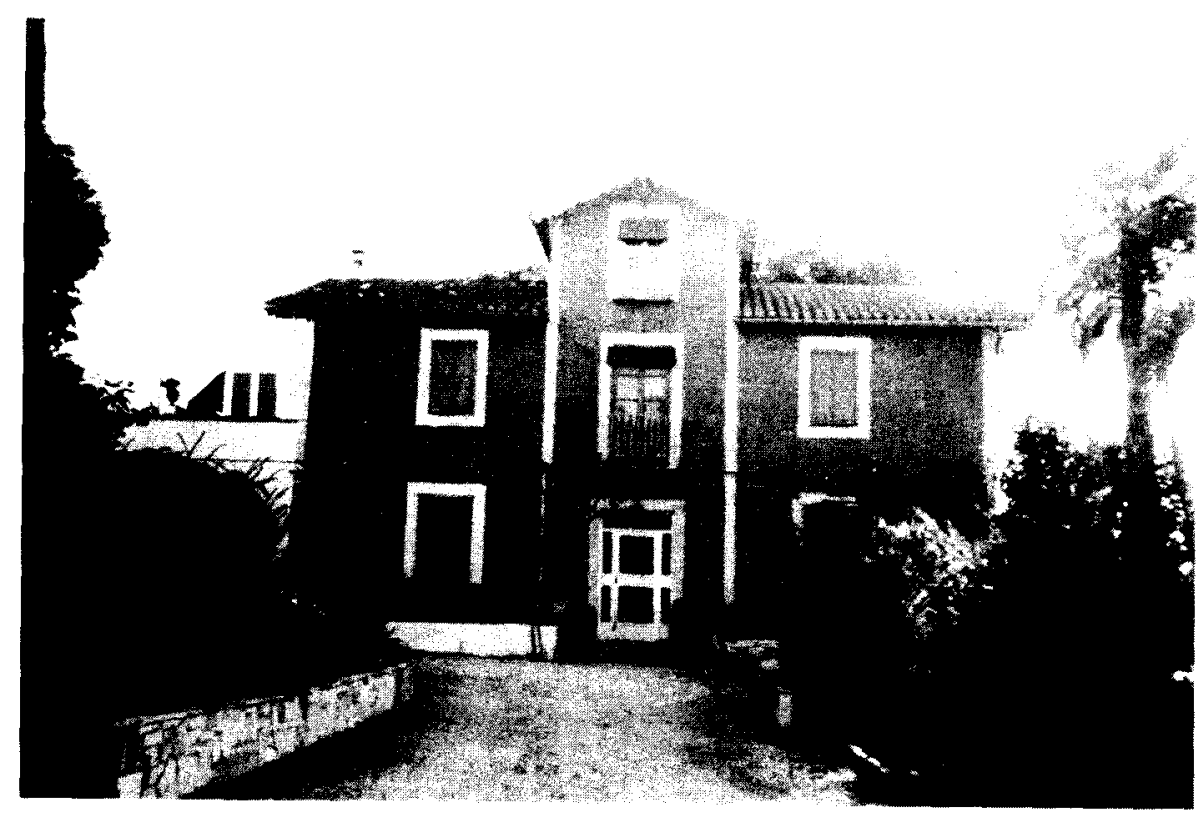

RESIDENCIA ANTIGUA. LAS ROTAS. Construcción de finales del siglo XIX. 
RAMONA CIUDAD CIUDAD

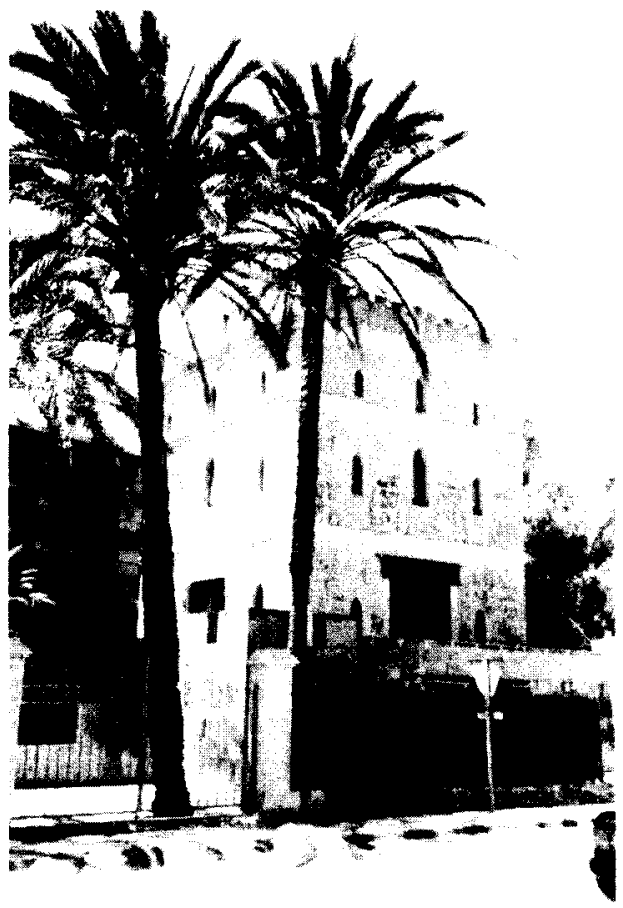

RESIDENCIAS DE LAS ROTAS.

Debajo, pequeña vivienda construida con el permiso de Costas,

aprovechando el desnivel que producen las rocas frente al mar al construir el paseo marítimo.

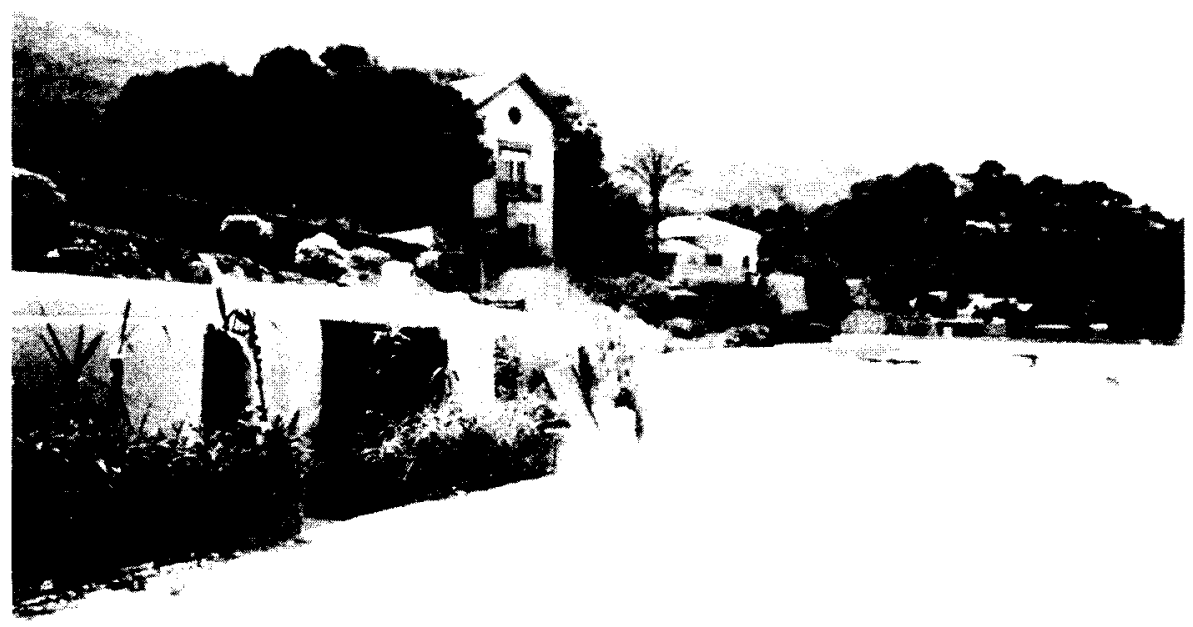

88 
Desde el siglo XVIII y sobre todo en el IXI el campo conoce un período de prosperidad. Son los años de las explotaciones masivas de la pasa. Esta conquista del espacio cultivado lleva aparejado un proceso semejante de colonización humana, que en algunos sitios supone una verdadera "urbanización del campo» por el gran número de viviendas que se construyen.

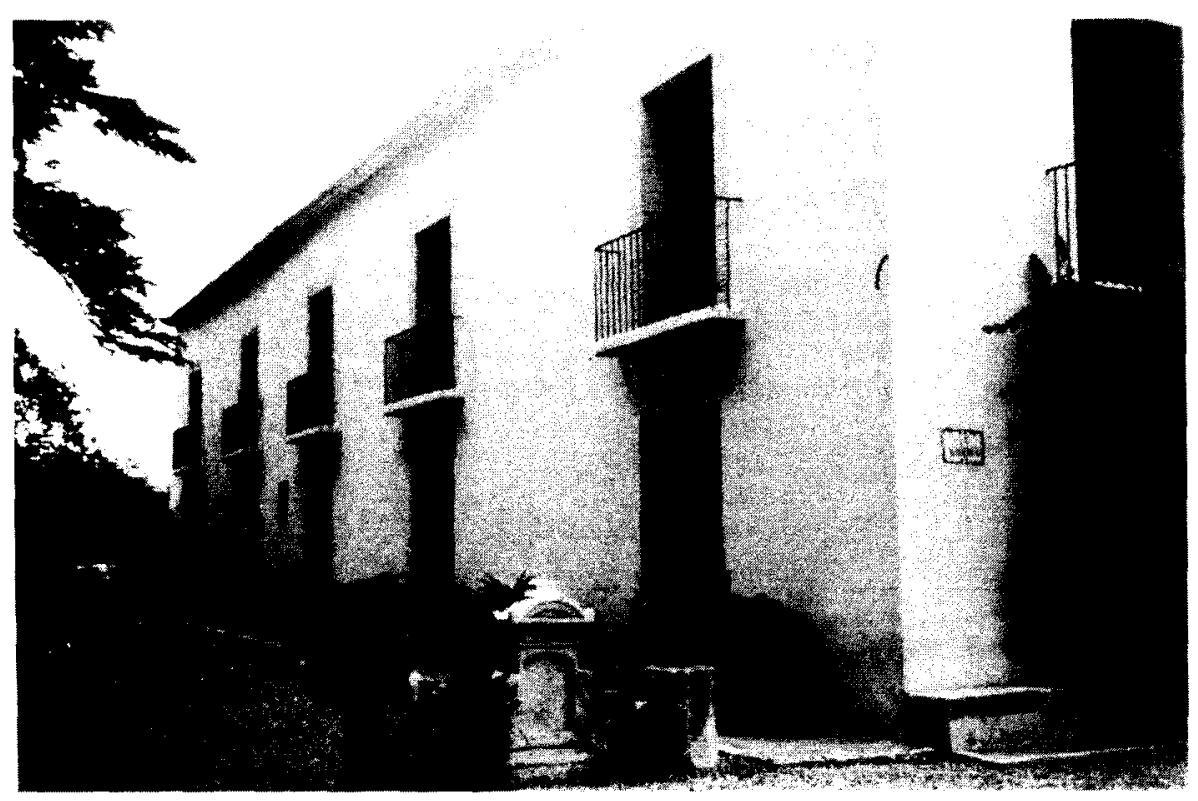

ALQUERIA.

Los estilos de éstas varían, desde el eclecticismo, pasando por las construcciones con clara influencia italiana palladiana, hasta las grandes casonas señoriales y las casas de labranza con los riu-rau característicos.

Con la crisis de la pasa debido a la plaga de la filoxera, las vides empiezan a ser reemplazadas por los naranjos, ocupando éstos, actualmente, la casi totalidad de la superficie cultivada.

Las invasiones de los piratas africanos que asolaban las costas hasta bien mediado el siglo XVIII, unido a la ampliación del regadio, cuyas áreas se alejan de la ciudad, exigen que la construcción de viviendas, en campos expuestos al saqueo, puedan rechazar el ataque exterior. 


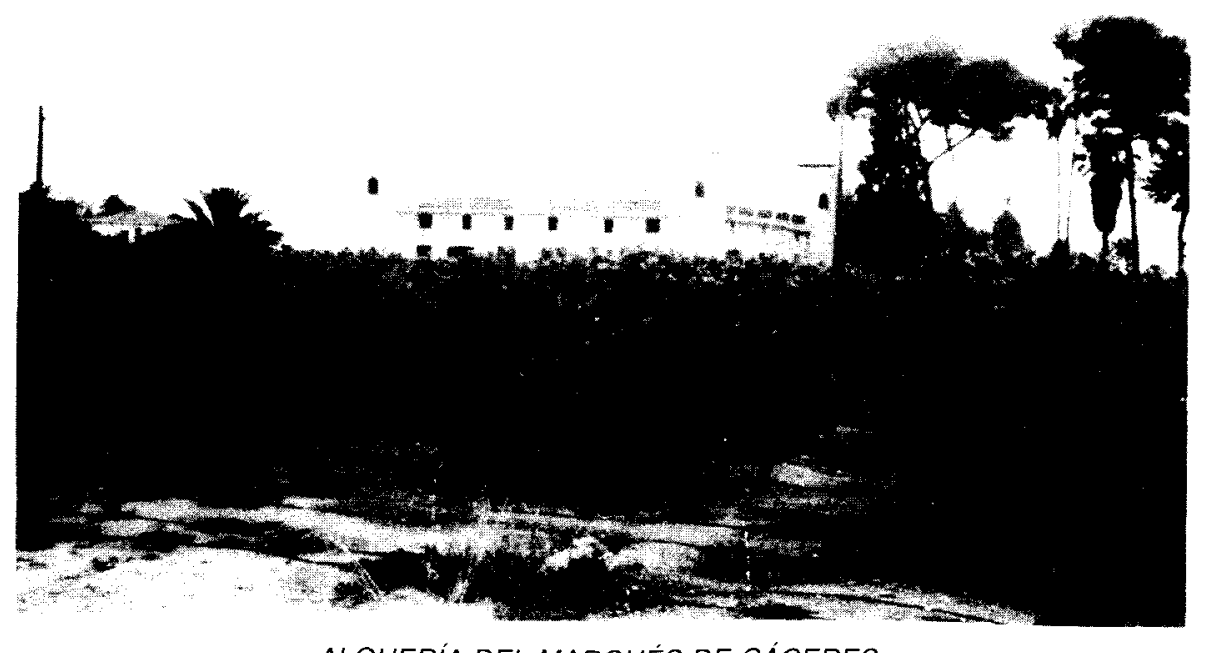

ALQUERIA DEL MARQUÉS DE CÁCERES.

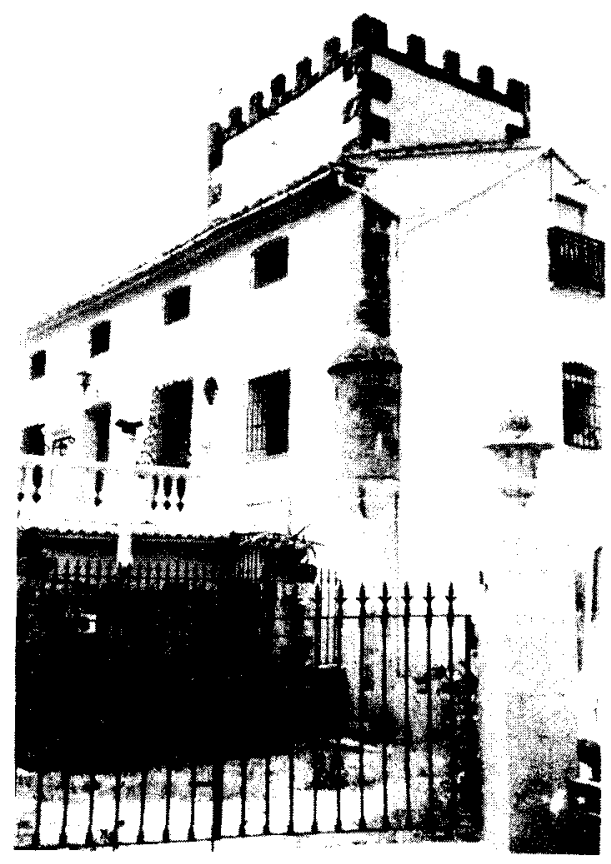


Así se levantan fuertes torres de piedra, a las que posteriormente se adosan las viviendas, protegidas por garitones en las esquinas. La "Torre Carrals" es un claro ejemplo de este tipo de construcciones.

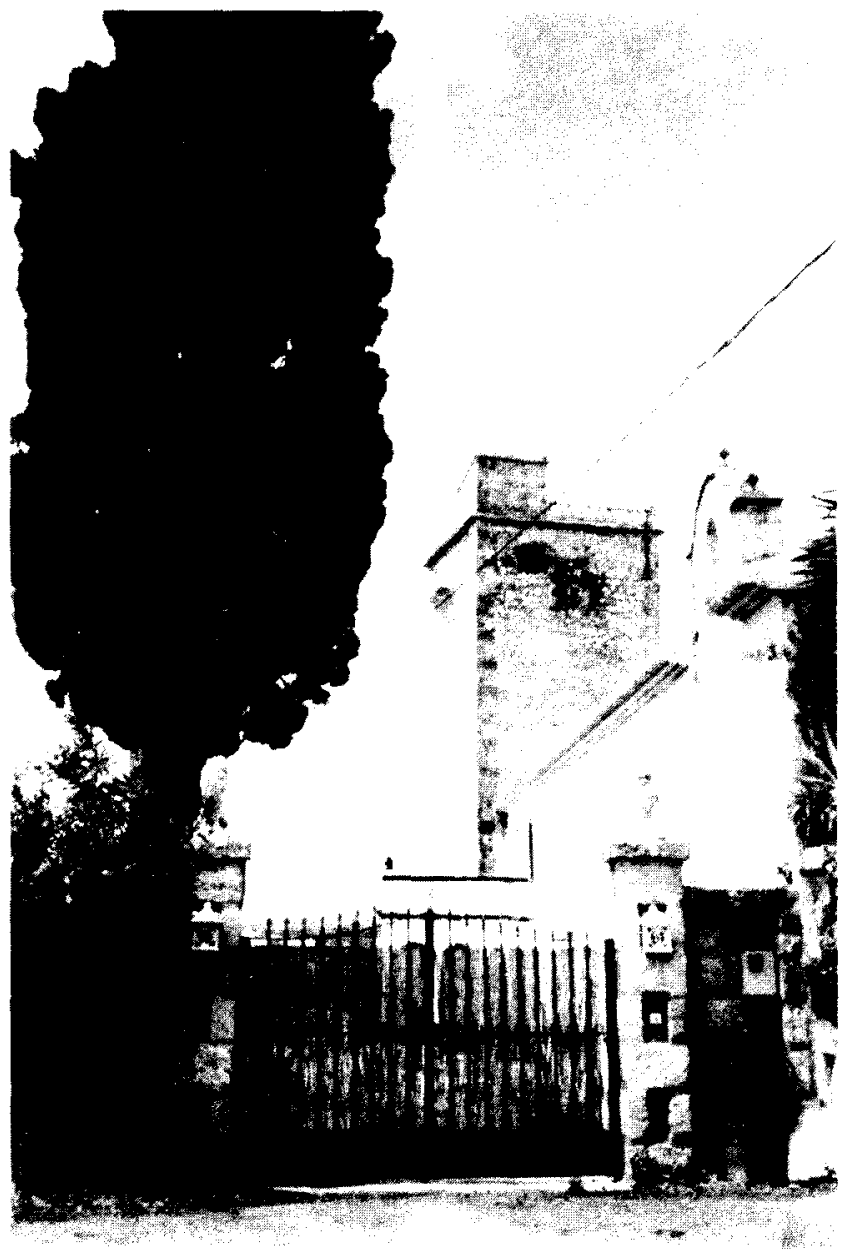

Al ser más atractivas las posibilidades económicas de la agricultura gracias al auge económico de la pasa, los terratenientes deciden construir sus casas, capaces, por un lado de manifestar el auge económico y, por otra, constituir el soporte de una auténtica explotación agricola. Los estilos de las construcciones varian, predominando el eclecticismo como en esta casa neomudejar, rodeada de un amplio jardín con una gran alberca en el centro del mismo. 


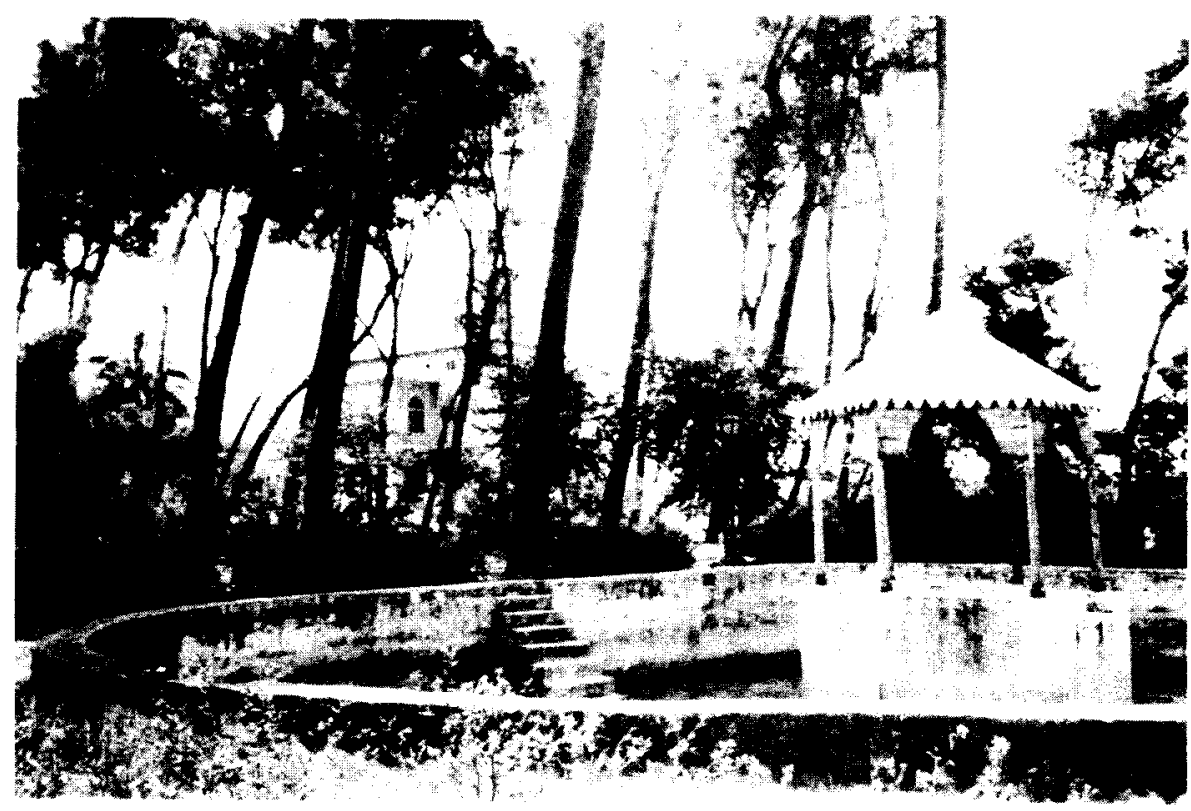

Las casas están rodeadas de una abundante vegetación que consigue un paisaje ciertamente espectacular. Al respecto nos dice Meliá Tena: “No sólo son útiles los naranjos, sino que amenizan y embalsaman el recinto: siempre vistosos por el verdor y brillo de sus hojas, por la multitud y fragancia de sus flores y por la hermosura de sus frutos, forman vergeles hermosos con los cuales alternan otros frutales, multitud de moreras y otros árboles. Recréase el ánimo al descansar bajo aquellas sombras, donde el gusto, la vista y el olfato reciben agradables impresiones.." ${ }^{23}$.

En este marco es donde los dueños deciden construir sus casas para descansar largas temporadas, favorecidos por la existencia del agua y la vegetación. El tipo más característico de vivienda es la cuadrada con torre. Las torres o huertos, como la de Francisco Merle, serviría de claro ejemplo de este tipo de construcciones.

La casa no se plantea exenta, sino que se integra en un conjunto orgánico, compuesta por la vivienda propiamente dicha y por las construc-

23 Meliá Tena, C.: “L'economia del regne de Valéncia segons Cavanilles". Valencia, 1978, pág. 108. 

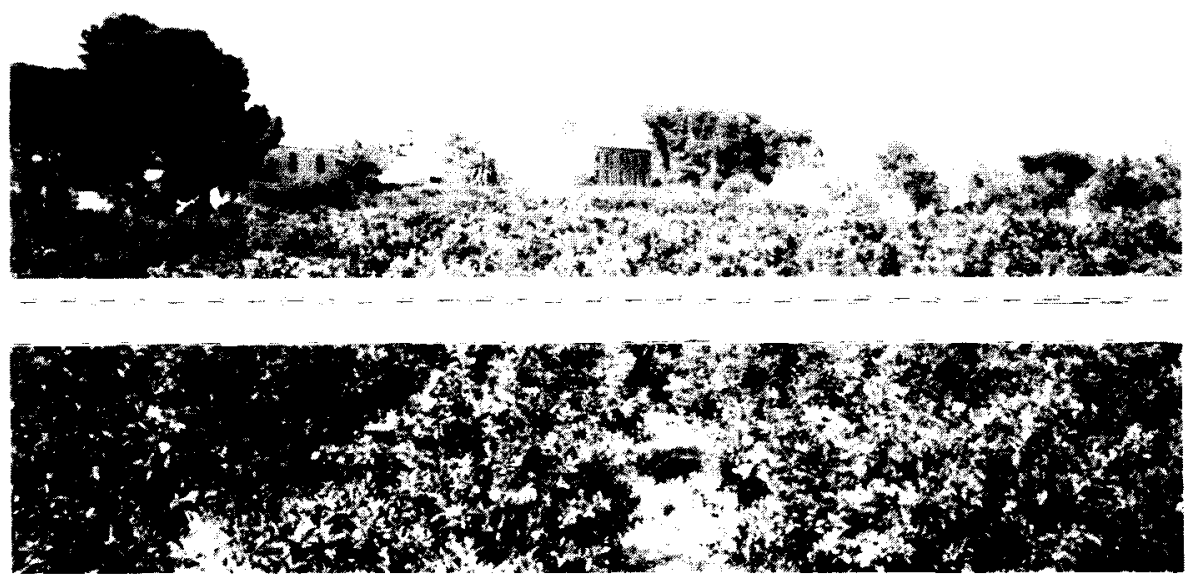

HUERTO DE FRANCISCO MERLE.

ciones auxiliares de carácter agrario. La influencia de los cultivos en la arquitectura rural ha sido determinante. El almacenaje de los productos y de los aperos de labranza son fundamentales en la construcción. La última planta de la vivienda rural (la cámara) era el almacén del grano y aceite y servía también para airear los productos de la matanza.

El nombre de alquería es excesivamente genérico. Seijó Alonso la define como "casa de grandes dimensiones, situada siempre en terrenos de regadío. Para Casas Torres, la alquería designa la casa de labranza, con ribetes de castillo, preparadas para albergar un gran número de personas, entre dueños y colonos, aunque, actualmente, este término se aplica a todas las casas aisladas, aunque las habite una sola familia, siendo su tamaño mayor que el habitual ${ }^{24}$.

Otro tipo de construcción son los riu-rau. Consiste en "un pórtico en arcadas o adintelado, unido al edificio principal, ya en su parte delantera, ya en uno de sus laterales, o bien separado totalmente de la casa, al otro extremo de la amplia era, que se emplea comúnmente para secadero de la pasa...

24 Seijó Alonso, F.: “La vivienda rural alicantina», Alicante, 1979, dos tomos, pág. 127. 

Las arcadas, escarzanas o de medio punto las sostienen aquí anchos pilares de manpostería, y su misión como ya se ha indicado es específica: guardar la pasa, si, estando al sol, el cielo amenaza tormenta. Se le puede dar otros usos complementarios, como guardar el carro, los aperos, la paja, etc....

Parece probable que hasta mucho tiempo después de la expulsión de los moriscos estas viviendas rurales no tuvieron mucha aceptación, pues las gentes estaban más seguras tras las murallas. Sus arcadas se abren casi siempre al E.» ${ }^{25}$.

Este espacio ventilado y sombreado protege la vivienda del calor y la luz exterior, sobre todo en el verano.

Áreas comerciales. La mayor parte de los servicios administrativos, de ocio, incluso sanitarios, se encuentran en la zona comercial, situada en la calle Marqués de Campo y cercanías: calle Diana, calle Cop, convirtiéndose dicha área en el C.B.D. de la ciudad. Por el contrario la ausencia de centros de servicios en el casco antiguo es manifiesta, limitándose éstos a algunas pequeñas tiendas de abastecimiento diario, lo cual acentúa aún más la degradación de los barrios históricos.

Este hecho provoca además una descompesación de las dotaciones en el espacio urbano, una gran concentración de tráfico en la calle Marqués de Campo y alrededores e implica una jerarquización de rangos en los espacios, cuya importancia en orden de decisión económica va decreciendo conforme vamos penetrando en la zona más antigua.

El hecho que cerca del área de decisión económica este ubicado el Mercado municipal y un gran supermercado genera una mayor actividad y tráfico de personas. Este espacio se completa con un abundante y variado comercio de uso personal (boutiques, joyerías, agencia de viajes y tiendas de objetos de regalo de lujo), lo cual aumenta la atracción de la población de las otras zonas de la ciudad.

Mientras que las calles Diana y Cop su función se limita al uso comercial, la calle Marqués de Campo es el centro neurálgico, donde además de la concentración del comercio, es el centro administrativo y social de la ciudad. Su carácter de alameda da lugar a que también sea una zona de paseo y ocio.

Sin embargo, las cada vez mayores necesidades de la población y lo reducido del espacio que aglutina las actividades comerciales ha provocado

25 Seijó Alonso, F.: obra citada págs. 145, 146, 148 y 158. 
que se desarrolle un cinturón, considerado como área de influencia de la calle Marqués de Campo, formado por las calles Colón, La Nar, Hospital, Explanada Cervantes y Plaza del Pais Valenciano.

La Explanada Cervantes, tiene el atractivo del puerto, lo que provoca también una gran concentración de lugares de ocio, restaurantes, derivándose hasta las inmediaciones del barrio marinero que, con su tipismo, lo hacen ser un importante núcleo de atracción turística.

El crecimiento de la ciudad y la creación del área de expansión de la misma, ha obligado a desarrollar otros centros comerciales y de servicios en estas zonas para el mejor funcionamiento de la ciudad y de las gentes que viven en este área que, aún siendo de menor categoría facilitan el abastecimiento diario.

Áreas industriales. En primer lugar hay que destacar su dispersión en el núcleo urbano, tanto en el casco antiguo - artesanado tradicional-, como en el área del ensanche de la ciudad -Avda. de Alicante, calle de Patricio Ferrándiz-, donde se concentran un gran número de industrias de juguetes, almacenes industriales y talleres de reparación del automóvil.

Las razones de ello son, por un lado, históricas, ya que el nacimiento de la industria, coincidió con la expansión urbana del siglo $|X|$, instalándose dicha industria en las áreas periféricas de la ciudad, cuyos solares tenian un precio más bajo y la facilidad de las comunicaciones -atracción del ferrocarril- facilitan su creación.

Por otro lado, la inexistencia de un área industrial claramente definida y con una infraestructura adecuada facilitó, aún más su dispersión, provocando una mayor condensación de tráfico y generando ruido y molestias para la ciudad.

Actualmente, el desarrollo del poligono industrial, programado en el Plan Urbanístico de 1972, ubicado en la vía principal de acceso a la ciudad -desviación de la A-7- y con una superficie de 41,18 Has. está en franco crecimiento.

Son, sin embargo, múltiples los interrogantes que nos suscita la creación de dicho polígono industrial a la entrada de una ciudad turística, cuya base económica está en el turismo. La falta de infraestructuras adecuadas es uno de los elementos a tener en cuenta: inexistencia de vías de acceso a las industrias ubicadas en él y la obligatoriedad de acceder a ellas directamente desde la vía principal.

Por otro lado, y aún teniendo presente que la industria necesita buenas comunicaciones para su desarrollo, nos planteamos si una ciudad de las 
características de Denia, cuya actividad económica radica, como hemos dicho anteriormente, en el turismo, tuviese como via principal de acceso, la zona de las Marinas, un área turística y no un área industrial.

Pese a todo lo anteriormente expuesto, el poligono industrial creado no ha provocado el desalojo de las industrias ubicadas en el interior de la ciudad, sobre todo, las más molestas, ya que todas ellas continúan instaladas y funcionando dentro de la ciudad, lo que significa que dicho polígono no ha servido como descongestión de la industria de la ciudad.

\section{Zonas verdes y espacios libres}

Hay que señalar, en primer lugar, la ausencia casi total de zonas de esparcimiento, entendiendo como tales las zonas verdes y espacios libres, no pudiendo aceptar como tales los señalados en el Plan Urbanístico que incluye, dentro de esta última tipología, plazas que son centros de confluencia de calles o simples zonas de aparcamiento. Sería el caso de las plazas del Archiduque Carlos, Valgamedios, Mariana Pineda, del Convento,...

Las zonas verdes son también muy escasas en la ciudad. Teniendo en cuenta que para conceptuarse como tales es necesario - según el P.G.U - tener una superficie no inferior a $1.000 \mathrm{~m}$. Una de las áreas planificadas como zona verde sería la ubicada en torno a la casa del historiador Chabás. Al mismo tiempo se reconoce que si la generalidad es de 15 jardines por cada 2.000 a 5.000 viviendas habría que crear 10 zonas de estas características.

También hay que destacar, no sólo la escasez de zonas de esparcimiento en la ciudad, sino también la casi inexistencia de arbolado -exceptuando la calle Marqués de Campo- en el área urbana.

\section{CONCLUSIONES}

En los capítulos precedentes hemos intentado esbozar una imagen de la situación actual de Denia, centrándonos en las características de su población y en la evolución que la ciudad ha llevado a cabo a lo largo de la historia hasta nuestros días.

La situación privilegiada de Denia ha determinado claramente su evolución. Tanto romanos como árabes la conocieron y supieron aprovecharse de ella, desarrollando una importante cultura de la que todavía existen importantes vestigios. 
El desarrollo del comercio de la pasa marcó el auge económico y supuso la transformación urbanística de la ciudad en el siglo IXI. Al mismo tiempo, este hecho, conllevó una transformación del paisaje agrario que vio cómo se roturaban nuevas tierras y el espacio rural se pobló de suntuosas villas y de innumerables casas de labranza. El puerto contribuyó, en gran medida, a este auge comercial.

Ahora bien, la década de los años 60 será la que proporcione un impulso revitalizador a la ciudad, después de la crisis de la filoxera y la guerra civil. El boom turístico acaecido en las costas mediterráneas supondrá una nueva etapa de desarrollo económico con un crecimiento demográfico importante, provocado también por los contingentes inmigratorios venidos a la ciudad de otras partes de la península.

Sin embargo, este despertar de Denia no estuvo exento de problemas. La necesidad de hacer frente a este crecimiento demográfico, conjuntamente con las inversiones de inmobiliarias y constructoras provocaron la construcción de viviendas cada vez más altas, obviando la estructura urbanística propia de la ciudad y destruyendo, en ocasiones, el patrimonio histórico y cultural de la misma.

Denia, capital de la comarca del Marquesado, su estudio y evolución puede hacernos comprender los problemas anteriormente planeados y puede servirnos de indicador para evitar un mayor deterioro de la ciudad y llevar a cabo una adecuada planificación del crecimiento de la misma, que evite la anarquía en la construcción, remodelar adecuadamente el casco antiguo y crear las infraestructuras necesarias para asegurar su crecimiento y desarrollo.

\section{BIBLIOGRAFIA}

CASAS TORRES, J. M.: La vivienda y núcleos de población rurales de la huerta de Valencia. Madrid, 1944.

Chabas, R.: "Historia de Denia", 1874, edición de 1985. Diputación Provincial de Alicante y Ayuntamiento de Denia.

ChOFRE GIL, J. M.: "1966-1976: Un decenio arroilador». Canalobre, revista del Instituto Juan Gil-Albert, número 9, 1987.

COLOMER,V; GARCía, J. J.; JARDÓN, R.: "Transformacions urbanístiques al litoral valencià. El cas de Les Marines de Denia". Comunicación presentada en el li Congreso de estudios de la Marina Alta (1984). Revista Aguaits, 1990.

COSTA MAS, J.: “El Marquesat de Denia”. U. Valencia

Del. Rey Aynat, M.: "Arquitecturas rurales dispersas en la comarca de la Marina". Colegio oficial de arquitectos de la Comunidad Valenciana. Instituto de Estudios Juan Gil-Albert. Alicante, 1986.

IVARS, J.: "Ciutat, Patrimoni arquitectónic i pla especial de protección. Canalobre, revista del Instituto Juan Gil-Albert, número 9, 1987.

IVARS, J.: "Evolucio, canvi y destrossa del paisatge urba». Canalobre, revista del Instituto Juan Gil-Albert, número 9, 1987. 
IVAas, J.: "La ciutat de Denia. Evolucio i permanencia del fet urban. Publicaciones de la Caja de Ahorros. Alicante. 1982.

Hervís Avilés, J. M., y Segovia Montoya, A.: "Arquitectura y color". Colegio Oficial de arquitectos de Valencia. Editora Regional de Murcia, 1983.

MARtin, G.: “La supuesta colonización griega de Hemeroskopeion. Estudio arqueológico de la zona Denia-Javea". Valencia, 1968.

MeLIA TENA, C.: "L'economia del regne de Valencia segons Cabanilles, Valencia, 1978.

SEIJÓ Alonso, F.: “La vivienda rural alicantina". Alicante, I y II tomos, 1979.

Plan General de Urbanización de las Playas Deveses, Almadraba, Marines: 1962. Archivo Municipal. Denia.

Plan de Reforma Interior y Extensión de las Zonas N. y S. de la Ciudad: 1966. Archivo Municipal. Denia.

Plan General de Ordenación Urbana de Denia: 1972. Archivo Municipal.

Plan Especial del. Patrimonio Histórico-Artistico y Modificación puntual del Plan General de DENIA. 1983. Archivo Nunicipal.

Plan General de Ordenación Utrana de denia: 1992.

Zarate Martín, A.: “El espacio interior de laciudad». Editorial Síntesis. Madrid, 1991. 